\title{
Standard methods for small hive beetle research
}

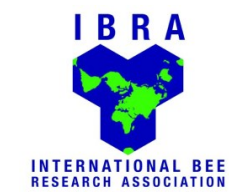

\section{Peter Neumann ${ }^{1,2^{*}}$, Jay D Evans ${ }^{3}$, Jeff S Pettis ${ }^{3}$, Christian W W Pirk ${ }^{2}$, Marc 0 Schäfer ${ }^{4}$, Gina Tanner ${ }^{1}$ and James D Ellis ${ }^{5}$}

${ }^{1}$ Institute of Bee Health, Vetsuisse Faculty, University of Bern, Bern, Switzerland.

${ }^{2}$ Social Insect Research Group, Department of Zoology \& Entomology, University of Pretoria, Pretoria, South Africa.

${ }^{3}$ USDA-ARS Bee Research Laboratory, Beltsville, Maryland, USA.

${ }^{4}$ National Reference Laboratory for Bee Diseases, Friedrich-Loeffler-Institute (FLI), Federal Research Institute for Animal Health, Greifswald Insel-Riems, Germany.

${ }^{5}$ Honey Bee Research and Extension Laboratory, Department of Entomology and Nematology, University of Florida, Gainesville, Florida, USA.

Received 28 March 2013, accepted subject to revision 20 June 2013, accepted for publication 15 July 2013.

*Corresponding author: Email: peter.neumann@vetsuisse.unibe.ch

\section{Summary}

Small hive beetles, Aethina tumida, are parasites and scavengers of honey bee and other social bee colonies native to sub-Saharan Africa, where they are a minor pest only. In contrast, the beetles can be harmful parasites of European honey bee subspecies. Very rapidly after $A$. tumida established populations outside of its endemic range, the devastating effect of this beetle under suitable climatic conditions prompted an active research effort to better understand and control this invasive species. Over a decade, $A$. tumida has spread almost over the entire USA and across the east coast of Australia. Although comparatively few researchers have worked with this organism, a diversity of research methods emerged using sets of diverse techniques to achieve the same goal. The diversity of methods made the results difficult to compare, thus hindering our understanding of this parasite. Here, we provide easy-to-use protocols for the collection, identification, diagnosis, rearing, and for experimental essays of $A$. tumida. We hope that these methods will be embraced as standards by the community when designing and performing research on $A$. tumida.

\section{Métodos estandar para la investigación del pequeño escarabajo de las colmenas}

\section{Resumen}

Los pequeños escarabajos de la colmena, Aethina tumida, son parásitos y carroñeros de la abeja de la miel y otras colonias de abejas sociales nativas de África subsahariana, donde sólo son una plaga menor. Sin embargo, los escarabajos pueden ser parásitos dañinos de las subespecies de abejas europeas. Muy rápidamente después de que $A$. tumida estableciera poblaciones fuera de su área endémica, el efecto devastador de este escarabajo en condiciones climáticas adecuadas impulsó un activo esfuerzo de investigación para comprender y controlar mejor esta especie invasora. En más de una década, $A$. tumida se ha extendido prácticamente por todos los EE.UU. y en toda la costa este de Australia. Aunque comparativamente son pocos los investigadores que han trabajado con este organismo, surgió una diversidad de métodos de investigación utilizando diversas técnicas para lograr el mismo objetivo. La diversidad de métodos complica la comparación de los resultados, lo que dificulta la comprensión de este parásito. Aquí, ofrecemos protocolos fáciles de utilizar para la recolección, la identificación, el diagnóstico, la crianza, y para ensayos experimentales con $A$. tumida. Esperamos que estos métodos se adopten como normas estándar por la comunidad para el diseño y la realización de investigaciones sobre $A$. tumida. 


\section{蜂箱小甲虫研究的标准方法}

\section{摘要}

蜂箱小甲虫 (Aethina tumida) 是源于撒哈拉以南非洲地区土著蜜蜂和其它社会性蜂群的一种寄生虫和食腐动物。在当地, 它们危害极小。但是 对于欧洲蜜蜂亚种, 这种甲虫却是有害寄生虫。小甲虫在其原产地以外建立种群后, 在适宜的气候条件下造成了破坏性的影响, 迅速促进了针对 了解和有效控制这一入侵物种的热点研究。十多年来, A . tumida几乎已经扩散至整个美国以及澳大利亚的东海岸。虽然针对这一物种的研究者 相对较少, 但是出现了针对同一研究目标利用不同技术手段的多样化研究方法。研究方法的多样性导致了研究结果难以进行比较, 妨碍了我们对 这一寄生虫的进一步认识。本章我们提供了有关 $A$. tumida的样品采集、鉴定、诊断和实验研究的简易方法。我们希望这些方法今后能被业内当 作针对 $A$. tumida的研究设计和实施的标准。 
Table of Contents
Page

No.

\begin{tabular}{|c|c|c|}
\hline 3.1.1.1. & SHB diet & 11 \\
\hline 3.1.1.2. & SHB maintenance and transport conditions & 11 \\
\hline 3.1.1.2.1. & Mass maintenance & 11 \\
\hline 3.1.1.2.2. & Individual maintenance & 11 \\
\hline 3.1.3. & Rearing techniques & 11 \\
\hline 3.1.3.1. & Rearing procedure & 11 \\
\hline 3.1.3.2. & Individual rearing approach & 14 \\
\hline 3.1.4. & Sex determination & 14 \\
\hline 3.1.4.1. & Sex determination of adults & 14 \\
\hline 3.1.4.2. & Sex determination of pupae & 14 \\
\hline 3.1.5. & Marking techniques & 15 \\
\hline 3.1.5.1. & Marking SHB larvae & 15 \\
\hline 3.1.5.2. & Marking adult SHB & 15 \\
\hline 3.1.5.2.1. & Feeding adult SHB with coloured food & 15 \\
\hline 3.1.5.2.2. & Thoracic notching of adult SHB & 16 \\
\hline 3.1.6. & $\begin{array}{l}\text { Effect of external conditions on SHB in the } \\
\text { laboratory }\end{array}$ & 16 \\
\hline 3.1.6.1. & Investigating diet effects on SHB reproduction & 16 \\
\hline 3.1.6.2. & Determining soil effects on SHB pupation & 17 \\
\hline 3.1.7. & $\begin{array}{l}\text { Transmission of bee pathogens by small hive } \\
\text { beetles }\end{array}$ & 17 \\
\hline 3.1.7.1. & $\begin{array}{l}\text { Investigating potential interactions between } \\
\text { A. tumida and Paenibacillus larvae, the } \\
\text { causative organism of American foulbrood }\end{array}$ & 18 \\
\hline 3.1.7.2. & $\begin{array}{l}\text { Investigating the potential of SHB to vector } \\
\text { honey bee viruses }\end{array}$ & 18 \\
\hline 3.1.8. & Investigations of SHB pathogens and parasites & 18 \\
\hline 3.1.8.1. & $\begin{array}{l}\text { Inoculating SHB larvae with entomopathogenic } \\
\text { fungi }\end{array}$ & 18 \\
\hline 3.1.8.2. & Infesting SHB with nematodes & 18 \\
\hline 3.1.8.2.1. & $\begin{array}{l}\text { In vitro infestation of wandering larvae with an } \\
\text { aqueous suspension of nematodes }\end{array}$ & 18 \\
\hline 3.1.8.2.2. & $\begin{array}{l}\text { In vitro soil infestation of larvae using a sand } \\
\text { bioassay }\end{array}$ & 19 \\
\hline 3.1.8.2.3. & $\begin{array}{l}\text { In vitro soil infestation of pupae with an } \\
\text { aqueous suspension of nematodes }\end{array}$ & 19 \\
\hline 3.1.8.2.4. & $\begin{array}{l}\text { In vitro soil infestation of pupae with nematode } \\
\text {-infected cadavers }\end{array}$ & 19 \\
\hline 3.2. & Field techniques & 19 \\
\hline 3.2.1. & $\begin{array}{l}\text { Investigating intra-colonial interactions } \\
\text { between adult bees and adult SHB }\end{array}$ & 19 \\
\hline
\end{tabular}




\begin{tabular}{|c|c|c|c|c|c|}
\hline \multicolumn{2}{|c|}{ Table of Contents cont'd } & \multicolumn{3}{|l|}{$\begin{array}{l}\text { Page } \\
\text { No. }\end{array}$} & $\begin{array}{l}\text { Page } \\
\text { No. }\end{array}$ \\
\hline 3.2.1.1. & General experimental establishment & 19 & 3.2.3.2. & $\begin{array}{l}\text { Counting the number and distribution of beetles } \\
\text { in freshly-killed colonies }\end{array}$ & 24 \\
\hline 3.2.1.2. & Behavioural categories & 20 & 3.2.3.2.1. & Killing with liquid nitrogen & 25 \\
\hline 3.2.1.3. & $\begin{array}{l}\text { Investigating behavioural interactions of adult } \\
\text { honey bees and adult SHB at the colony } \\
\text { entrance - two alternative options }\end{array}$ & 21 & 3.2.3.2.2. & Killing with petrol fuel & 25 \\
\hline 3.2.2. & $\begin{array}{l}\text { Investigating SHB oviposition behaviour and } \\
\text { bee hygienic responses to SHB eggs and young } \\
\text { larvae }\end{array}$ & 22 & 3.2.3.2.3. & Freeze killing & 25 \\
\hline 3.2.2.1. & $\begin{array}{l}\text { Promoting SHB oviposition behaviour in capped } \\
\text { bee brood }\end{array}$ & 22 & 3.2.3.3. & $\begin{array}{l}\text { Counting the number of beetles and defining } \\
\text { their spatial distribution in winter clusters killed } \\
\text { by dipping in liquid nitrogen }\end{array}$ & 25 \\
\hline 3.2.2.2. & $\begin{array}{l}\text { Identifying and marking brood cells in which } \\
\text { SHB have oviposited }\end{array}$ & 23 & 3.2.4. & Collecting SHB eggs & 26 \\
\hline 3.2.2.3. & $\begin{array}{l}\text { Determining honey bee hygienic responses to } \\
\text { SHB eggs and young larvae }\end{array}$ & 23 & 3.2.5. & Introducing adult SHB into colonies & 26 \\
\hline 3.2.2.4. & $\begin{array}{l}\text { Determining proportion of perforated capped } \\
\text { brood cells containing SHB eggs (oviposition } \\
\text { rate) }\end{array}$ & 24 & 4. & Acknowledgments & 27 \\
\hline 3.2.3. & $\begin{array}{l}\text { Determining the number and distribution of } \\
\text { adult SHB inside a field colony and winter } \\
\text { clusters and starting colonies without SHB }\end{array}$ & 24 & 5. & References & 28 \\
\hline 3.2.3.1. & $\begin{array}{l}\text { Visually screening the number of beetles in live } \\
\text { colonies and/or removing beetles to start beetle } \\
\text {-free colonies }\end{array}$ & 24 & & & \\
\hline
\end{tabular}

\section{Introduction}

Aethina tumida (Coleoptera: Nitidulidae) was named and described in 1867 by Andrew Dickson Murray in the Annals and Magazine of Natural History London (Murray, 1867). He received two specimens originating from Old Calabar, on the west coast of Africa. Small hive beetles (SHB) are parasites and scavengers of honey bee and other social bee colonies native to sub-Saharan Africa, where they are considered to usually be a minor pest only (Lundie, 1940; Schmolke, 1974; Hepburn and Radloff, 1998; Neumann and Elzen, 2004; Neumann and Ellis, 2008). In 1996, SHB were discovered outside of their native range in colonies of European subspecies of honey bees in the southeastern USA (Elzen et al., 1999; Hood, 2004). Since then, $\mathrm{SHB}$ introductions have been reported from a number of other countries (Neumann and Elzen, 2004; Ellis and Munn, 2005; Neumann and Ellis, 2008). In these new ranges, the beetles can be harmful parasites of colonies of European honey bee subspecies (Elzen et al., 1999; Hood, 2004) and may also damage colonies of non-Apis bees such as bumble bees and stingless bees (Spiewok and Neumann, 2006a; Hoffmann et al., 2008; Greco et al., 2010; Halcroft et al., 2011). Very rapidly after $A$. tumida established populations outside of its endemic range, the devastating effects of this beetle on honey bee colonies (given suitable climatic and soil conditions, Ellis et al., 2004c) resulted in an active research effort to better understand and control this pest. Over a decade, $A$. tumida has spread and established almost over the entire USA and across the east coast of Australia (Neumann and Ellis, 2008). Although comparatively few laboratories have worked with this organism, a range of different research methods emerged. Here we provide an overview on methods in the field and in the laboratory for experimental essays of $A$. tumida, which we hope will be embraced as standards by the community when designing and performing research on SHB.

\section{Diagnostics and sampling}

Small hive beetle research requires diagnostic as well as experimental approaches and involves a wide range of different techniques for laboratory and field trials. For both, diagnostics as well as experiments it is crucial to find and identify the SHB. Knowledge about beetle appearance and location in the colony during the different developmental stages is necessary to work with this pest.

\subsection{Beetle appearance during the different developmental stages}

\subsubsection{Eggs}

A. tumida eggs are pearly-white and about $2 / 3$ the size of a honey bee egg (Fig. 1) and can usually be found in typical egg-clutches (Lundie 1940). Normally, eggs hatch in about three days, occasionally in up to six days (Lundie, 1940). In low relative humidity, egg hatching may be reduced (Somerville, 2003; Stedman, 2006). 


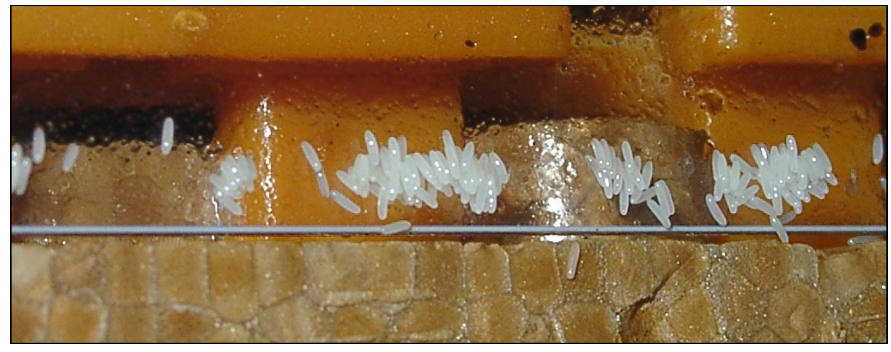

Fig. 1. Small hive beetle eggs oviposited in clutches in a honey bee mating nucleus colony. They are $\sim 1.4 \mathrm{~mm}$ in length and $\sim 0.26 \mathrm{~mm}$ in width (Lundie, 1940).

Photo: Peter Neumann.

\subsubsection{Larvae}

SHB larvae are creamy-white and emerge from the egg shell through a longitudinal slit at the anterior end (Lundie, 1940). After hatching, the larvae are about $1.3 \mathrm{~mm}$ long and grow to a final size of about 8.6 to $10.5 \mathrm{~mm}$ in length (Schmolke, 1974; Fig. 2). Larval development takes 10-14 days, but may extend to 30 days, depending on food resources and temperature (Stedman, 2006). They have three pairs of legs close to the head, a characteristic row of paired dorsal spines on each segment and two larger paired spines protruding sub terminal on the rear end of the dorsum which distinguishes it from the greater wax moth larvae (Galleria mellonella).

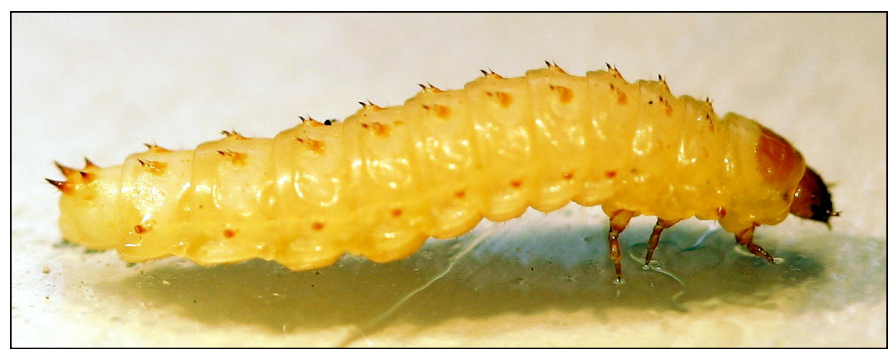

Fig. 2. Small hive beetle larvae. The post-feeding wandering stage is

shown. Photo: Marc Schäfer.

\subsubsection{Pupae}

A. tumida pupae are free pupae (pupa libera), which means that their extremities such as legs and wing sheaths are, in contrast to pupa obtecta, not glued to the body (Fig. 3). Pupae in early stages (Fig. 3a) are pearly-white with a series of characteristic projections on the thorax and the abdomen, but darken as they develop (Fig. 3b) and their exoskeleton hardens, with pigmentation first appearing in the eyes and then the under wings (Lundie, 1940). Depending on soil temperature pupation time varies between 15 - 74 days (Neumann et al., 2001a), but may take up to 100 days in cold periods (Stedman, 2006). During eclosion, the puparium bursts and the adult beetle emerges (Fig. 3c).

\subsubsection{Adults}

Adult $A$. tumida beetles (Fig. $3 d$ ) are about $1 / 3$ the size of a honey bee worker. They are oval-shaped and vary in size ranging from 5 to $7 \mathrm{~mm}$ in length and 3 to $4.5 \mathrm{~mm}$ in width. The adults' bodies are broad and dorsoventral flattened. For a short period after emergence, they are coloured reddish-brown (Fig. 3c), but during maturation they darken to dark brown or even black (Fig. 3d). The head, thorax and abdomen are well separated. Their elytra are short, so that a few segments of their abdomens are visible, and their antennae are distinctively club shaped. The entire body is covered with short, fine hair.

Note: Caution must be taken not to confuse SHB with closely related Nitidulidae beetles. This is especially true for Cychramus /uteus, which might be easily confused with not fully mature adult SHB (Neumann and Ritter, 2004, Fig. 4). In cases of doubt, species status should be confirmed based on definitive morphological characteristics (e.g. shape of ovipositor and antennae, coloration, shape of pronotum, length of elytra, and other defined attributes, Freude et al., 1967).
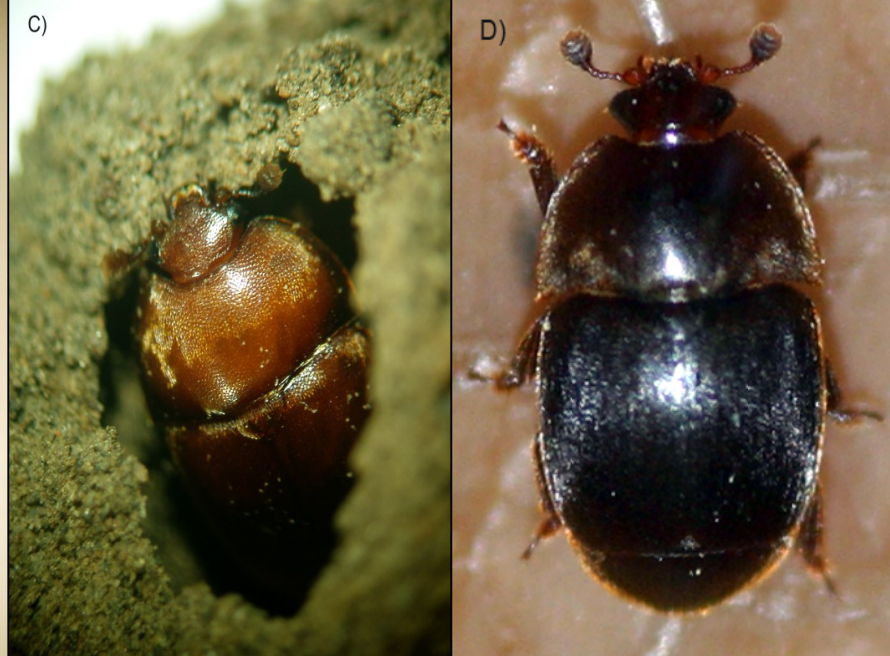

Fig. 3. Small hive beetle pupae and adults: $\boldsymbol{A}$. early pupal stage; $\boldsymbol{B}$. late pupal stage; $\boldsymbol{C}$. adult ready to emerge from pupation chamber; D. adult on honey bee comb (dorsal view) with typical antenna and short elytra. Photos A-C: Anna Röttger; D: Nelles Ruppert. 


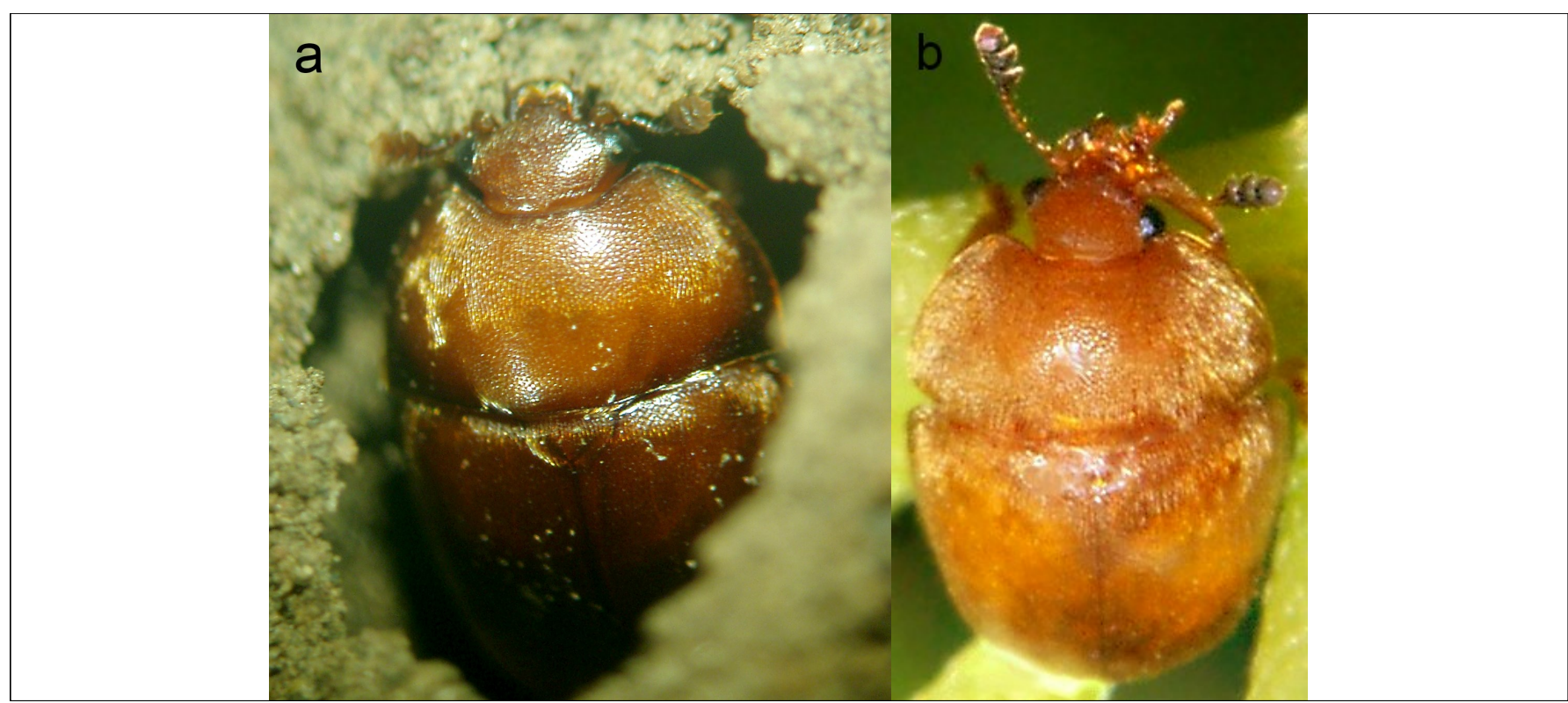

Fig. 4. Adult beetles of the family Nitidulidae, which are associated with honey bee colonies: $\boldsymbol{a}$. Aethina tumida ready to emerge from the pupation chamber. Photo: Anna Röttger; b. Cychramus luteus. Photo: Frank Koehler.

The following SHB characteristics are most useful to distinguish them from other nitidulids in the field:

- Broadened ends of club shaped antennae are as long as wide

- $\quad$ Short wing cases: end of abdomen is visible

- Spiky edges on the lateral margins of the pronotum.

\subsection{Beetle locations during the different}

\section{development stages}

\subsubsection{Eggs}

A. tumida eggs are mostly deposited in clutches (Fig. 1) that can be found anywhere within the hive. Females appear to prefer crevices or cavities for oviposition (Neumann and Härtel, 2004), however, eggs can also be found on combs or underneath sealed honey combs (Neumann and Hoffmann, 2008) or directly with the honey bee pupae underneath the cell cappings (Ellis et al., 2003f; Ellis and Delaplane, 2008).

\subsubsection{Larvae}

All stages of larvae may be found crawling on and in the combs where they especially pierce the cappings and side walls of rather fresh combs. By contrast, older combs with several layers of cocoons seem to withstand penetration better. Larvae can also be found underneath sealed honey combs (Neumann and Hoffmann, 2008) and on the bottom boards provided that sufficient food can be found in the debris (e.g. dead adult bees, Spiewok and Neumann, 2006b). Fully grown, so-called wandering larvae (Fig. 5; Lundie, 1940) may also be found on the ground surrounding the infested colony, where they search for suitable earth to pupate, e.g. underneath hives. Larvae can also be spotted in apicultural facilities (e.g. honey houses) given low sanitary standards or unsuitable storage conditions for (honey) combs or other material. Please note that SHB wandering larvae can crawl considerable distances to find suitable soil (> 200 m, Stedman, 2006). SHB larvae have rarely been reported outside of hives, apiaries and other apicultural facilities (e.g. occasionally in fruit buckets, Buchholz et al., 2008).

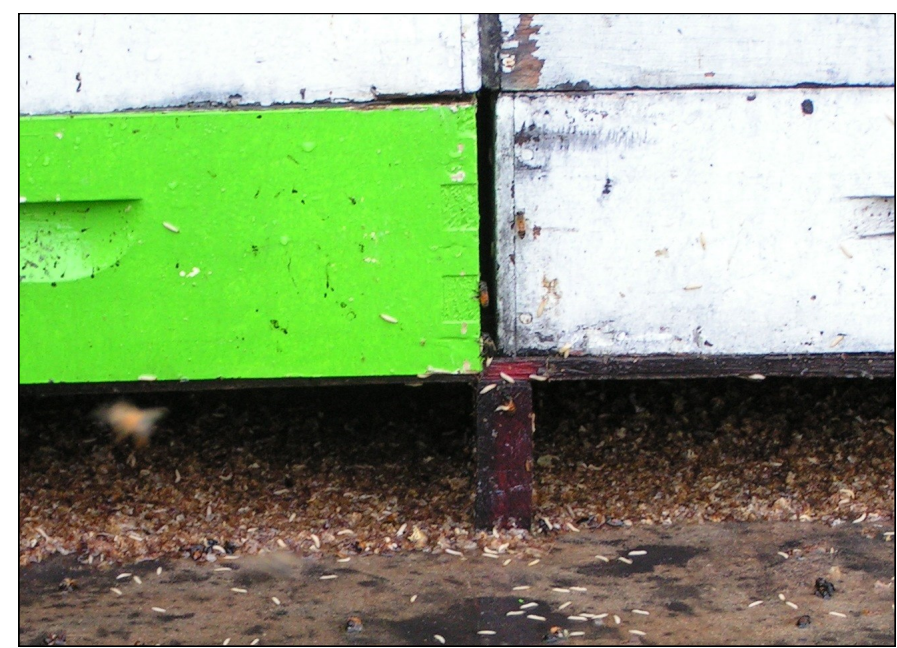

Fig. 5. Small hive beetle wandering larvae underneath hives.

Photo: Peter Neumann.

\subsubsection{Pupae}

Pupation takes place in the soil surrounding the colony in individual chambers at shallow depth (seldom deeper than $20 \mathrm{~cm}$, de Guzman et al., 2009). Pupae can be carefully sieved out of the soil of a cavity (sieve: $20 \times 20 \mathrm{~cm}$; mesh width: $1 \mathrm{~mm}$ ) and then be collected with tweezers or an aspirator (Pettis and Shimanuki, 2000). 


\subsubsection{Adults}

In the hive, SHB are regularly found everywhere, where they can hide from bees or in areas of the hive with low bee densities, but seem to prefer bottom boards (up to $40 \%$ of the hive SHB population, Neumann and Hoffmann, 2008). Most SHB are prevented from freely roaming the hive because honey bees defend against SHB by chasing and corralling them into confinement sites (Neumann et al., 2001c; Ellis, 2005). Beekeepers working a colony often open these confinement sites, which sets the beetles free and running over the hive material. Nevertheless, adult SHB are often notoriously difficult to spot during colony surveys due to their dark coloration and their tendencies to avoid sunlight and hide in corners or underneath material. Outside of the hives, adult SHB can often be spotted in honey houses and underneath hives, pending local beetle population density and sanitation efficacy of the respective beekeeper(s) (Spiewok et al., 2007; 2008). Besides hives and apicultural facilities adult SHB have rarely been reported (e.g. in fruit buckets, Buchholz et al., 2008).

\subsection{Shipped bee samples}

Rapid detection and identification of SHB is crucial to limit further distribution of this species. To prevent the beetle from being introduced to other areas or countries, imported queens, worker bees or honey bee colonies should be inspected carefully. In any case, suspect honey bee sample shipments from countries where SHB is known to be present should be immediately sent to the respective national reference laboratory or competent authority for examination and identification.

\subsubsection{Inspection of honey bee queen shipments for small} hive beetle

When receiving a shipment of honey bee queens that are to be inspected for presence of small hive beetle, the following methods can be used:

1. Remove the queen from queen cage and visually inspect her for signs of SHB (adult, larval, or egg stages; Fig. 1-3) or any other potentially introduced species, such as the mites Tropilaelaps spp. (see the BEEBOOK paper on Tropilaelaps (Anderson et al., 2013)) or Varroa destructor (see the BEEBOOK paper on Varroa (Dietemann et al., 2013)).

2. Store queen appropriately (e.g. in a colony), according to local procedures and regulations.

3. Immediately place the shipping container and queen cage, including the worker attendants, in a sealable bag and store in a freezer for at least 24 hours to kill attendants and any introduced species such as SHB or Tropilaelaps spp.

4. Perform a second visual inspection on the queen cage, the dead worker attendants, the shipping container and other accompanying materials as quickly as possible after the freeze period.

Note: A similar protocol can be applied if inspecting shipped worker honey bees.

\subsection{Sampling of adult small hive beetles}

For many experimental studies it is necessary to collect small hive beetles in the field. Aethina tumida can be sampled not only directly from honey bee colonies (Neumann and Hoffmann, 2008), but also from their surroundings (Pettis and Shimanuki, 2000). Several techniques can be used for the sampling of SHB.

\subsubsection{Manual collection}

For the manual collection of adult SHB, many devices are feasible to use (e.g. battery operated vacuums) and can be modified for SHB collection. However, the easiest and most common ones are aspirator devices and suction devices (e.g. Spiewok et al., 2007; 2008; Neumann and Hoffmann, 2008, Fig. 6), which are widely used for collection of insects in general. Such aspirators consist of a container for the specimen and two tubes connected to the container. A longer tube allows suction by connecting the container to the collector's mouth, while a shorter tube guides a targeted insect into the container. The longer tube is covered with cloth mesh to prevent accidental aspiration of the specimen. As this method is very easy and requires no prearrangements, we recommend this method for any type of collection of SHB, but especially for collection at apiaries which are visited only once and where none of the following methods can be applied.

Note: It is highly recommended to clearly label the two tubes differently to avoid accidental inhalation of SHB and bees during collection.

\subsubsection{Traps in colonies}

Several devices to trap adult SHB inside colonies are available. All of them have entrances which allow SHB to enter but exclude honey bees. Most of these traps use mineral or vegetable oil as a killing agent. There are traps available for all positions in the hive: under the bottom board, on the bottom board, in the frame, as a replacement for a frame, between frame top bars, and at the entrance of the hive. Two very similar devices that are widely used are the "Beetle Eater ${ }^{\circledR "}$ and the "Beetle Blaster ${ }^{\circledR "}$. Both are designed to be placed between two frame top bars either in the bottom chamber or in supers. Most of these in-hive trapping-devices are designed to kill SHB and only allow an approximately measurement of the SHB infestation rate of colonies. For collection of live SHB for laboratory studies, we recommend a very simple method to catch adult SHB inside of the colonies using diagnostic strips (Schäfer et al., 2008; 2010a). These devices are made of corrugated plastic strips $(75 \times 500 \times 4 \mathrm{~mm})$ which create rows of narrow tunnels for SHB to hide in, but prevent access of bees. Diagnostic strips have a mean capture efficacy of $30 \%$ of the colony SHB population, and provide a fast, cheap, and easy quantitative diagnosis for estimating SHB population sizes in the field (Schäfer et al., 2008). Furthermore, in light of the very efficient detection rate $(96.3 \%)$, these diagnostic strips are also a suitable tool 


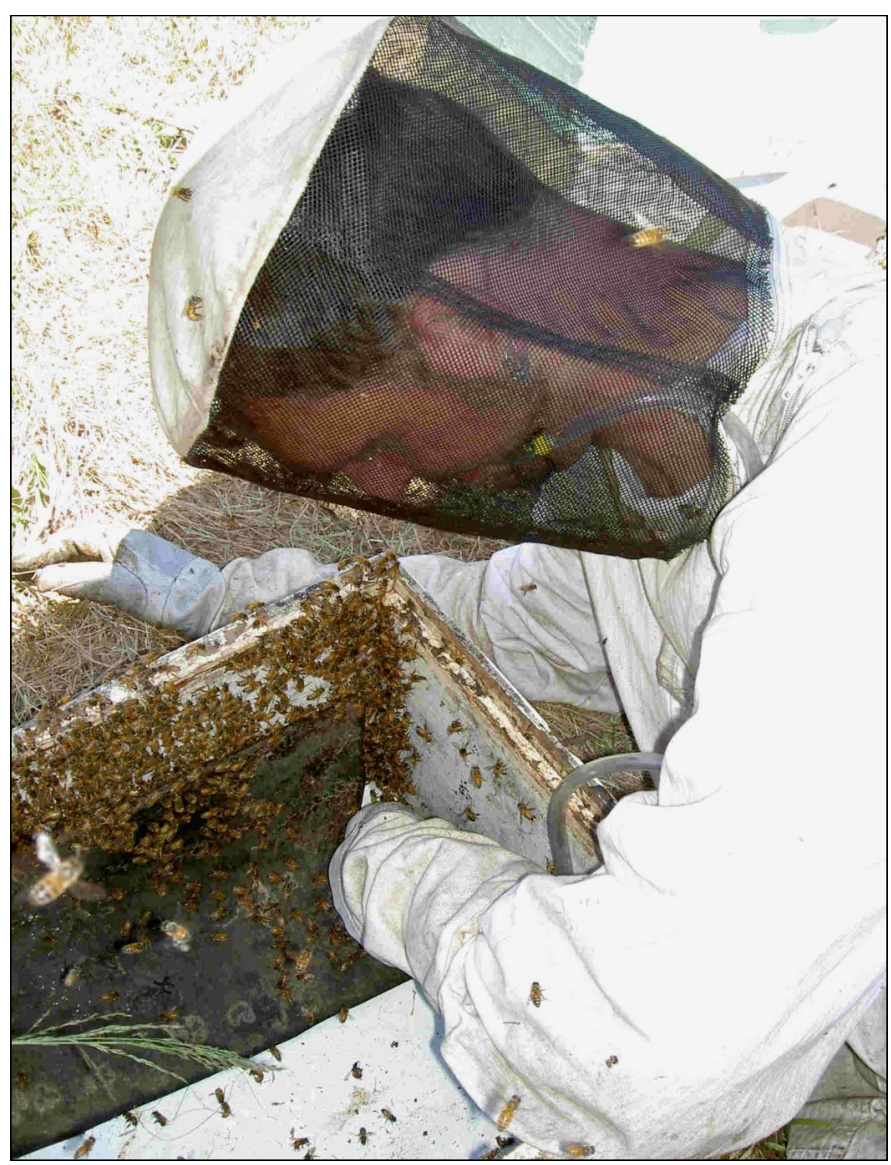

Fig. 6. Manual collection of small hive beetle adults in a hive using an aspirator (for details please refer to Neumann and Hoffmann (2008)).

Photo: Dorothee Hoffmann.

to screen colonies in areas, where SHB have not been reported yet (Schäfer et al., 2010a). This will foster a fast sanitation response to prevent SHB spread given accidental introductions. Please refer to the Portugal case for successful prevention of SHB spread (Murilhas, 2005) and to Australia/USA for consequences of too late detections (Neumann and Ellis, 2008). Usage is as follows (Schäfer et al., 2008; 2010a):

1. Place one diagnostic strip on the bottom board of a colony by sliding it through the flight entrance (Fig. 7).

2. Leave the strips in the hives for two nights to provide SHB time to find the refuges.

3. Remove the strips by pulling them out quickly and shake the enclosed SHB into bright trays for counting or for collection with an aspirator or other suction devices (see section 2.4.1.).

Note: Caution must be taken with respect to both bottom board debris (boards should be clean to allow no space below the trap in which SHB can crawl) and ambient weather conditions. For example, under cold conditions sample SHB from bee clusters, where beetles cluster with the resident bees for warmth (Pettis and Shimanuki, 2000; Schäfer et al., 2011).

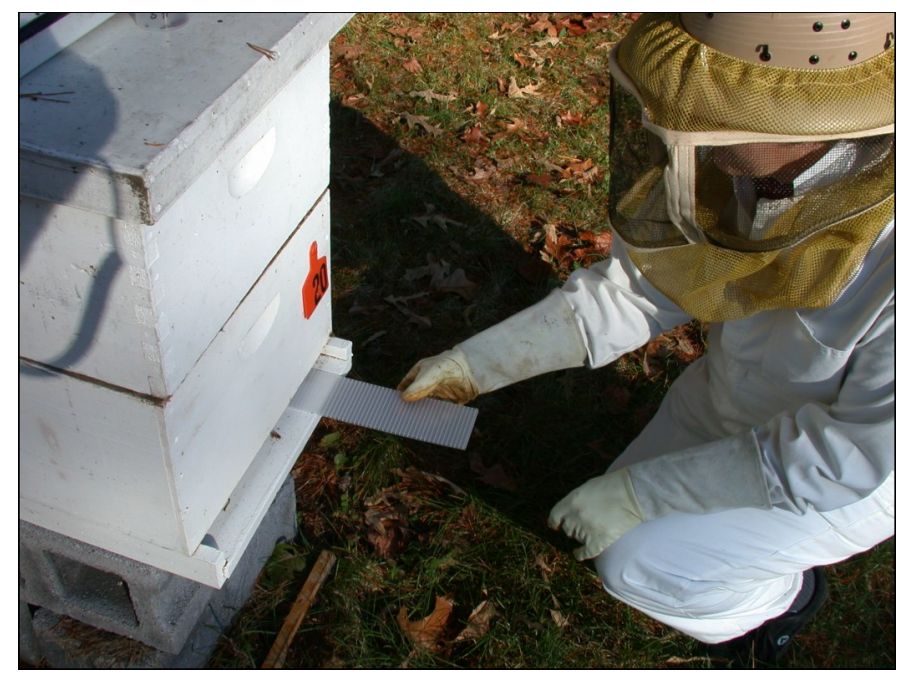

Fig. 7. Usage of diagnostic strips to detect adult small hive beetles. The strips are placed on the bottom board of a hive by sliding it through the flight entrance. Special care must be taken that the bottom boards are clean and even to avoid SHB hiding underneath the strips and not inside.

Photo: USDA.

\subsubsection{Traps outside of colonies}

\subsubsection{Trapping of adult small hive beetles}

A variety of different traps and baits have been used to capture adult SHB outside the hive (Elzen et al., 1999; Arbogast et al., 2007; Benda et al., 2008; Buchholz et al., 2008; Neumann and Hoffmann, 2008; de Guzman et al., 2011). Plastic bucket traps with 8-mesh hardware cloth glued across $7 \mathrm{~cm}$ diameter holes (large enough for adult beetles to enter) have been used to trap SHB outside of colonies. Selection of an attractive bait is critical to capture of SHB outside the hive environment. While a mixture of honey, pollen, and adult bees showed the highest catch numbers in the field (Elzen et al., 1999), fruits were not efficient (Buchholz et al., 2008). Arbogast et al. (2007) used pollen dough inoculated with the yeast Kodamaea ohmeri (Benda et al., 2008) as bait in traps made of $25.5 \mathrm{~cm}$ PVC pipe sections with a removable cap at each end. Two openings covered with 4-mesh screen allowed beetles to enter the trap.

An 18-mesh screen inverted cone, located just below the openings, funnelled SHB into the bottom cap through a small hole in the cone apex. Traps of this type positioned at $46 \mathrm{~cm}$ (same height as colony entrances) showed the highest catch numbers in the field.

Although these traps generally do not catch high numbers of beetles, these traps allow for continuous observations that provide a relative measure of $A$. tumida migration (de Guzman et al., 2011).

\subsubsection{Trapping of small hive beetle larvae}

To our knowledge, the wandering larvae trap (mounted on the entrance of the colony) of Arbogast et al. (2012) is the only published trap that captures wandering larvae at a colony scale. The trap 
consists of two parts constructed of three-eighths inch $(0.95 \mathrm{~cm})$ acrylic plastic held together by catches. The lower part of the trap is water tight and half filled with a solution of detergent and water. The upper part intercepts the larvae and is covered, except for a $3 \mathrm{~mm}$ gap at the level of the bottom board. Larvae enter through this gap and fall through a screen (18 gauge stainless steel wire with $2 \mathrm{~mm}$ openings). The screen prevents bees from falling into the detergent solution. The trap is attached to the bottom board by two $18 \mathrm{~cm}$ extensions on the upper part. We recommend the trap primarily as a research tool for colony-wide SHB population dynamics.

Note: Please see the original publications for a drawing of the trap.

\subsubsection{Storage and shipment of SHB samples}

Storage and shipping conditions obviously depend on the planned subsequent analyses (e.g. for viruses see the BEEBOOK paper by de Miranda et al., 2013). For morphometric analysis, the samples should be immediately preserved in $70-95 \% \mathrm{EtOH}$. This ensures that the specimens are suitable for this kind of analyses for at least a few months, and often considerably longer. Alternatively, for later usage in DNA analysis, the samples should be stored in a freezer at $\leq-20^{\circ} \mathrm{C}$ to slow down the degeneration of DNA in tissues. DNA from specimens frozen at $-20^{\circ} \mathrm{C}$ remains viable for several years, but to remain viable for longer, samples should be stored at $-70^{\circ} \mathrm{C}$ (for details please refer to section 9.3. in 'Storing dead adults' in the BEEBOOK paper on miscellaneous methods by Human et al., 2013). If SHB samples are shipped for scientific purposes, it is important to note that no living material should be sent to avoid the further distribution of this honey bee pest. Adult beetles or larvae should be first killed by over-night freezing or by soaking the specimen in $70-95 \% \mathrm{EtOH}$, and sent in a sealed container.

\subsubsection{Molecular diagnostics}

Below we describe and reference tools for using modern molecularbiology techniques to diagnose SHB. They can also be used to gain knowledge about the introduction(s) of this beetle from Africa into and among the current ranges (Lounsberry et al., 2010). This will elucidate pest populations and invasion pathways and contribute to knowledge of how this parasite expands in new populations (Lounsberry et al., 2010). These tools will also enable future studies to better understand SHB behaviour, health, and other aspects of their biology. We here cover only DNA techniques.

\subsubsection{DNA extraction}

For rapid DNA analyses, including genotyping with the markers described below, an extraction step is necessary:

1. Place one leg from an adult SHB into a $1.7 \mathrm{ml}$ centrifuge tube.

2. Grind with a disposable pestle.

3. Add $200 \mu \mathrm{l}$ of $5 \%$ Chelex $^{\circledR}-100$ solution (Bio-Rad Corp.; Walsh et al., 1991).
4. Vortex the solution.

5. Incubate for $15 \mathrm{~min}$. at $95^{\circ} \mathrm{C}$ and $30 \mathrm{~min}$. at $55^{\circ} \mathrm{C}$ before cooling.

6. Remove aliquots of $1 \mu \mathrm{l}$ from this solution, which will suffice for genetic tests.

When removing these aliquots, care must be taken to avoid including the Chelex ${ }^{\circledR}$ resin, as this can inhibit the next steps.

Alternate extraction methods for long-term use of DNA (e.g. the 'CTAB' method and the commercial DNEasy kit from Qiagen) are also effective and are described in detail in the BEEBOOK paper on molecular methods by Evans et al., (2013). Extractions of legs are advised since this avoids the heavily pigmented elytra, which can lead to inhibition of enzymatic assays and procedures.

\subsubsection{Mitochondrial DNA analyses}

The mitochondrion, a maternally inherited organelle, provides numerous genetic polymorphisms that can be useful for inferring sources for new SHB populations and for some small-scale studies of populations. Mitochondrial DNA (mtDNA) sequences for this species have been analysed for the gene encoding the Cytochrome oxidase I enzyme, a gene often used for DNA 'barcoding' (species-level and population-level identification) in insects. Evans et al. (2000) described two oligonucleotide primers, AT1904S (5'-GGTGGATCTTCAGTTGATTTAGC-3') and AT2953A

(5'-TCAGCTGGGGGATAAAATTG-3') that amplify a ca. 1,000 base-pair region of the SHB mitochondrion. These can be amplified and analysed as below:

1. Amplify using a thermal cycling protocol of

- $93^{\circ} \mathrm{C}(1 \mathrm{~min}$.$) ,$

- $54^{\circ} \mathrm{C}(1 \mathrm{~min}$.),

- $72^{\circ} \mathrm{C}$ (2 min.) for 35 cycles,

- followed by a $5 \mathrm{~min}$. elongation step at $72^{\circ} \mathrm{C}$.

2. Prepare a $1 \%$ agarose gel in $1 X$ TAE buffer by mixing:

2.1. $10 \mathrm{X}$ solution of $48.4 \mathrm{~g}$ of Tris base (tris (hydroxymethyl) aminomethane),

2.2. $11.4 \mathrm{ml}$ of glacial acetic acid (17.4 M),

2.3. $3.7 \mathrm{~g}$ of EDTA, disodium salt.

2.4. Bring to a final volume of $1 \mathrm{I}$ with deionized water.

2.5. Mix $1 \mathrm{~g}$ agarose/100 $\mathrm{ml}$ gel buffer.

2.6. Microwave in an Erlenmeyer flask for ca. $1 \mathrm{~min}$.

2.7. Swirl the liquids.

2.8. Microwave again for ca. $1 \mathrm{~min}$.

Solution should reach a rapid boil and be fully dissolved.

2.9. Let cool for $10 \mathrm{~min}$.

2.10. Add $1 \mu \mathrm{l}$ of $10 \mathrm{mg} / \mathrm{ml}$ Ethidium bromide per $100 \mathrm{ml}$ of gel volume.

3. Prepare sucrose loading buffer by mixing:

- $4 \mathrm{~g}$ sucrose,

- $25 \mathrm{mg}$ bromophenol blue or xylene cyanol (0.25\%),

- $\mathrm{dH}_{2} \mathrm{O}$ to $10 \mathrm{ml}$. 
4. Mix $3 \mu \mathrm{l}$ of each sample with $2 \mu \mathrm{l}$ sucrose loading buffer.

5. Load each sample in an individual well.

6. Include a DNA size standard in a well alongside the products (e.g. the 100 base-pair ladder from Invitrogen).

7. Electrophorese the products at ca. $100 \mathrm{~V} / 25$ amps (depending on gel apparatus) in a horizontal gel rig.

8. Visualize under UV light.

There should be a single strong band at ca. 1,000 base pairs.

9. Purify the resulting products (e.g. PCR Purification Kit, Qiagen).

10. Sequence from each direction via standard Sanger dideoxy sequencing (see the BEEBOOK paper on molecular methods, Evans et al., 2013) and the amplification primers.

Sequences can be aligned against numerous SHB haplotypes in public sequence databases (e.g., http://www.ncbi.nlm.nih.gov/ gquery/?term=aethina+tumida) to determine novelty or placement into a described haplotype.

\subsubsection{Microsatellite analyses}

Microsatellites are regions containing tandem repeats of 1-six-nucleotide repeats that are widespread in eukaryotic genomes including that of the SHB (please refer to Evans et al., 2013 for details). For example a $\mathrm{CA}_{12}$ microsatellite has 12 adjoining ' $C \mathrm{~A}^{\prime}$ ' nucleotides in the middle of non-repetitive DNA. These regions are inherently unstable, adding and clipping repeat units during cell replication and recombination. As a result, individuals often differ from each other in their genotypes at these loci, and they offer a powerful tool for describing populations and gene flow. Several microsatellite loci have been described for the SHB (Evans et al., 2008) and these loci have proven useful in mapping the movement of SHB in the Americas (Lounsberry et al., 2010). Below is a protocol for genotyping using dinucleotide (CA) microsatellites.

1. Prepare $5 \mu$ reaction mixes for each sample and primer containing:

- 1 Unit Taq DNA polymerase with appropriate $1 \mathrm{X}$ buffer (Invitrogen),

- $1 \mathrm{mM}$ dNTP mix,

- $2 \mathrm{mM}$ added $\mathrm{MgCl}_{2}$,

- $0.2 \mu \mathrm{M}$ of each forward and reverse primer,

- $0.08 \mu \mathrm{M}$ of the Forward primer end-labelled on the $5^{\prime}$ end with FAM or HEX fluorophores (ordered from Invitrogen, or another supplier).

2. Carry out the polymerase chain reaction (PCR) with a cycling program of

- $96^{\circ} \mathrm{C}$ for 2 min., then

- 3 cycles of $96^{\circ} \mathrm{C}$ for $30 \mathrm{sec}$.

- $60^{\circ} \mathrm{C}$ for $30 \mathrm{sec} .\left(-1^{\circ} \mathrm{C} / \mathrm{Cycle}\right)$,

- $65^{\circ} \mathrm{C}$ for $1 \mathrm{~min}$. followed by 35 cycles of

- $\quad 96^{\circ} \mathrm{C}$ for $30 \mathrm{sec}$.,
- $\quad 56^{\circ} \mathrm{C}$ for $30 \mathrm{sec}$.

- $\quad 65^{\circ} \mathrm{C}$ for 1 min., and

- a final extension at $65^{\circ} \mathrm{C}$ for $2 \mathrm{~min}$.

3. Add $1 \mu \mathrm{l}$ each PCR product (diluted $1: 20$ ) to $10 \mu \mathrm{l}$ Formamide containing 1X LIZ size standard (Applied Biosystems, ABI).

4. Determine labelled product size via one capillary gel run using an ABI 3730 DNA machine and GeneMapper software (e.g. version 3.7, ABI)

5. Carry out population-genetic analyses with the programs GenAlex (Peakall and Smouse, 2006), STRUCTURE (Falush et al., 2007) or other software programs designed to assess multi-allelic data, see section 3.3.2. on DNA microsatellites of the $B E E B O O K$ paper on methods for characterising subspecies and ecotypes of Apis mellifera (Meixner et al., 2013).

\subsubsection{Screening hive debris for $S H B$}

Since adult SHB show cryptic behaviour, they are notoriously difficult to spot in hives. Moreover, beetles are highly migratory (Spiewok et al., 2008; Neumann et al., 2012) and may have left the hive prior to inspection. We therefore recommend the following molecular method to screen imported hives for SHB (modified after Ward et al., 2007):

1. Extract DNA from hive debris samples:

1.1. Place $\sim 10 \mathrm{~g}$ samples of debris into grinding mill canisters (Kleco, Visalia, California, USA).

1.2. Add CTAB (Hexadecyltrimethylammoniumbromide, (Sigma)) lysis buffer (12\% Sodium phosphate buffer $\mathrm{pH}$ 8.0, 2\% CTAB, $1.5 \mathrm{M} \mathrm{NaCl})$, (20 ml) containing $1 \%$ antifoam B (Sigma) to each canister.

2. Seal canisters.

3. Load onto Kleco grinding mill.

4. Ground for $2 \mathrm{~min}$. at top speed.

5. Pour the lysate from each canister into a $50 \mathrm{ml}$ Falcon tube.

6. Spin the tubes at $4,000 \mathrm{~g}$ for $5 \mathrm{~min}$.

7. Remove $2 \mathrm{ml}$ of the cleared lysate.

8. Place into a $2 \mathrm{ml}$ micro-centrifuge tube.

9. Spin for a further $3 \mathrm{~min}$. at $10,000 \mathrm{~g}$.

10. Transfer cleared lysate $(1 \mathrm{ml})$ to a fresh $2 \mathrm{ml}$ micro-centrifuge tube.

11. Add $250 \mu$ of lysis buffer B (Promega) and $750 \mu \mathrm{l}$ of precipitation buffer (Promega).

12. Vortex.

13. Spin tubes at $10,000 \mathrm{~g}$ for $10 \mathrm{~min}$.

14. Transfer clarified extract $(750 \mu l)$ to a fresh micro-centrifuge tube.

15. Add $50 \mu \mathrm{l}$ of kit MagneSil ${ }^{\mathrm{TM}}$ beads and $600 \mu \mathrm{l}$ of isopropanol.

16. Incubate tubes at RT for $10 \mathrm{~min}$.

17. Extract DNA from each sample using the robotic magnetic particle processor (Kingfisher $\mathrm{mL}$, Thermo Labsystems) in conjunction with the Promega DNA purification system for food kit following the instructions of the supplier. 


\subsubsection{Future genetic work with $S H B$}

The SHB is well poised for genomic studies of olfaction (finding colonies to exploit or finding other SHB for mating), reproduction, and symbioses with fungi and other microbes. Hence, analyses of genomic and transcriptomic (high-throughput sequencing of expressed genes) traits in the SHB are sure to follow. The methods for these analyses will be identical to those used previously for honey bees and other insects, and these methods are described in the BEEBOOK paper on molecular methods (Evans et al., 2013).

\section{Techniques for experimental investigations}

The experimental work with SHB can basically be divided into two main categories; laboratory and field experiments. The following part of this manual includes recommendations and protocols of previously applied methods for various investigations.

\subsection{Laboratory techniques}

\subsubsection{Maintaining adult SHB in the laboratory and transport}

\subsubsection{SHB diet}

SHB feed and reproduce on honey, pollen, and most rapidly, on bee brood (Lundie, 1940; Ellis et al., 2002b). A diet of bee brood alone is impractical, however, because (1) many colonies are needed to produce enough brood to sustain a SHB rearing program, especially a large one, (2) of the destructive nature of removing brood from a colony and (3) using brood is not economical (a full brood frame can be easily consumed by the offspring of $10-15$ breeding pairs; Neumann et al., 2001a).

Although other Nitidulidae are often reared on fruits (see Peng and Williams, 1990b), rearing SHB on fruits alone is impractical because of the beetle's low fecundity on such diet (Ellis et al., 2002b; Buchholz et al., 2008). We also recommend avoiding artificial diets (like that proposed for rearing multiple species of Nitidulidae, Peng and Williams, 1990a), because of the general expense of artificial diets, the difficulty one has in obtaining the ingredients, and to keep the diet of SHB as natural as possible. One successful semi-defined SHB diet consists of dry granulated pollen, honey, and a honey bee protein supplement (e.g. Brood Builder ${ }^{\mathrm{TM}}$, Dadant and Sons, Inc.; Hamilton, IL, USA or Booster bee Protein Feed ${ }^{\mathrm{T} M}$, Beequipment South Africa, Mike Miles) mixed together in a 1:1:2 volume ratio. The exact ratio varies depending on how moist the honey is:

To make the diet,

1. Add in a large stand mixer the three ingredients

- $2000 \mathrm{ml}$ of pollen,

- $2000 \mathrm{ml}$ honey,

- $4000 \mathrm{ml}$ protein supplement

2. Mix for about $20 \mathrm{~min}$. until the mixture has a firm but pliable consistency.

This recipe makes enough for $20,400 \mathrm{~g}$ sections of diet.

3. If sticky, add protein supplement to the diet mixture incrementally until it is no longer sticky.

The diet should not be sticky to the touch because larvae feeding on a sticky substrate are able to crawl up vertical surfaces (their bodies become sticky) and are difficult to collect.

4. Provide water ad libitum.

\subsubsection{SHB maintenance and transport conditions}

Whenever maintaining or transporting adult SHB individually or en masse for experimental purposes, it is recommended besides ad libitum water supply to avoid direct sunlight exposure, to keep temperatures in general low (RT) and to allow for sufficient air circulation, since unsuitable storage conditions can quickly result in death (Peter Neumann, unpublished data).

\subsection{Mass maintenance}

1. Provide autoclaved glass containers with food (see 3.1.1.1.) and water ad libitum (or not in case starving is required).

2. Place adult SHB in the glass containers.

3. Adjust SHB numbers according to experimental needs (single, pairs, groups).

4. Store containers at RT in darkness.

\subsection{Individual maintenance}

1. Provide $0.5 \mathrm{~g}$ food (see section 3.1.1.1.) in standard Eppendorf ${ }^{\circledR} 1.5 \mathrm{ml}$ reaction tubes.

2. Place them in laboratory trays and puncture the lids with a needle (3-4 small holes) to allow air circulation and feeding.

3. Place individual adult SHB in the Eppendor ${ }^{\circledR}$ tubes using tweezers and seal them.

4. Store trays at RT in darkness.

5. Provide to each tube honey : water in a 1:1 ratio daily by carefully pipetting via the small holes.

Notes: The SHB can be maintained for up to 8 weeks in darkness at RT. Take care to seal containers quickly to limit SHB escape. To enable ovary activation in female SHB, use protein-rich food (see section 3.1.1.1.) instead of honey : water in a 1:1 ratio. Ensure that water is always provided ad libitum to prevent SHB dehydration.

\subsubsection{Rearing techniques}

\subsubsection{Rearing Procedure}

The rearing procedure is summarized in Table 1.

1. Conduct all laboratory manipulations with adult SHB under a screened insect cage to prevent adult escape.

2. Place 25 sexually mature adult pairs (see section 3.1 .4 .) into a 3 I plastic mating container with $\sim 400 \mathrm{~g}$ of SHB diet. No other 
Table 1. Summary of SHB mass rearing procedure.

\begin{tabular}{|c|c|c|c|}
\hline Number & Description & Maintained at: & Duration \\
\hline 1 & $\begin{array}{l}50 \text { adult SHB with } 400 \mathrm{~g} \text { diet in a plastic container } \\
(\sim 3 \text { I volume })\end{array}$ & $25^{\circ} \mathrm{C}$, no light, $>80 \%$ humidity & 2 weeks \\
\hline 2 & $\begin{array}{l}\text { Remove adults from container; SHB eggs, larvae, and food } \\
\text { present }\end{array}$ & $25^{\circ} \mathrm{C}$, no light, $>80 \%$ humidity & 2 weeks \\
\hline 3 & $\begin{array}{l}\text { Mature larvae }+ \text { food placed on ridged tray } \\
(\text { e.g.: } 45 \times 35 \times 6 \mathrm{~cm}, \mathrm{I} \times \mathrm{w} \times \mathrm{h} \text { with } 4 \text { ridges } 8 \mathrm{~cm} \text { apart } \\
\text { running the width of the tray) }\end{array}$ & $\begin{array}{l}25^{\circ} \mathrm{C} \text {, no light, humidity needs } \\
\text { to be high enough to keep } \\
\text { larvae from desiccating }\end{array}$ & $\begin{array}{l}>99 \% \text { larvae will leave } \\
\text { the food }<5 \text { days and } \\
\text { can be collected }\end{array}$ \\
\hline 4 & $\begin{array}{l}80 \mathrm{ml} \text { mature larvae added on top of } \sim 1.75 \text { I sandy soil in a } \\
\text { plastic container ( } 25.5 \mathrm{~cm} \text { height, } 15 \mathrm{~cm} \text { diameter, } 3.7 \text { I } \\
\text { capacity); add another } \sim 1.75 \text { I sand to burry larvae }\end{array}$ & $\begin{array}{l}25^{\circ} \mathrm{C} \text {, constant light for } 1 \text { week, } \\
\text { then no light }\end{array}$ & 20 days \\
\hline 5 & Place funnel trap on pupation container & $25^{\circ} \mathrm{C},>80 \%$ humidity, full light & $\begin{array}{l}\text { In } 2-5 \text { days, }>80 \% \text { of } \\
\text { adults will be in top } \\
\text { container }\end{array}$ \\
\hline 6 & $\begin{array}{l}\text { Remove funnel from trap and } \\
\text { store adult SHB in top container }\end{array}$ & $\begin{array}{l}25^{\circ} \mathrm{C},>80 \% \text { humidity, light } \\
\text { optional }\end{array}$ & $\begin{array}{l}\text { Adults will survive } 8+ \\
\text { weeks. Adult mortality } \\
\text { will increase over time }\end{array}$ \\
\hline
\end{tabular}

substrate, including wax comb or water should be placed in a mating container, because the inclusion of additional materials makes future larval collection difficult. Each container should be fitted with a lid ventilated with tiny holes.

3. The mating containers should be kept at $25^{\circ} \mathrm{C},>80 \%$ humidity with no light in incubators for 14 days to promote SHB reproduction and oviposition.

A high relative humidity is needed because SHB egg hatch rate is positively correlated with humidity (Jeff Pettis, unpublished data cited in Somerville, 2003).

4. Following the 2 week oviposition period, remove the adult beetles from the old diet with an aspirator, leaving the SHB eggs and larvae behind.

5. Transfer the adults in a new mating container with $400 \mathrm{~g}$ of beetle diet to continue the rearing program.

SHB diet should not be reused because old diet supports mould and fungus growth and may promote increased mortality in SHB larvae and pupae.

6. Move the mating containers from which the adult SHB were removed (they contain old diet, eggs, and developing larvae) to a second incubator for 2 weeks under similar conditions. Larvae are thus allowed additional time to develop in the absence of adult beetles.

7. Following the 2 week larval growth period, place the larvae and food opposite of a hole $(\sim 5 \mathrm{~cm})$ cut into the bottom at the far end of a tray that has raised $(2 \mathrm{~cm})$ ridges spaced $5-8 \mathrm{~cm}$ apart that run the width of the tray.

Larvae developing on the recommended beetle diet are not sticky and are unable to crawl up the tray walls (= dry rearing approach;
Neumann and Härtel, 2004). Any moisture added at this part of the procedure permits larvae to escape the tray.

8. Post-feeding mature larvae (wandering stage, Lundie, 1940) become positively phototactic, wander away from the diet in search of soil and fall through the hole on the opposite end of the tray. The ridges in the tray prevent the beetle diet from spreading over the tray and falling down the hole.

9. Place a second walled tray (same dimensions as aluminium tray) under the hole of the first to collect the falling wandering larvae.

10. Maintain the trays at $25^{\circ} \mathrm{C}, \sim 40 \%$ humidity, and no light for 5 days.

Placement of the larvae trays in a dark room encourages the larvae to crawl away from the diet when finished feeding. This takes advantage of a biological characteristic of the larvae, which normally leave bee colonies during the night. The larvae will remain hidden in the diet if maintained under constant light.

11. Collect the wandering larvae daily from the bottom tray as long as they are observed wandering from the food (usually up to 4 days).

Collected larvae are ready to pupate in the soil.

12. To facilitate pupation, half fill cylindrical plastic containers (pupation containers, $25.5 \mathrm{~cm}$ height, $15 \mathrm{~cm}$ diameter, 3.7 I capacity) with $\sim 1.75$ I sandy autoclaved soil (see section 3.1.6.2.) that is $\geq 10 \%$ moisture by mass.

13. Add about 2,000 wandering larvae ( $\sim 80 \mathrm{ml}$ larvae at 25 larvae/ml) to a pupation container and bury the larvae with $\sim 1.75$ I additional moist sand.

This number of individuals added to the chamber seems to create an 
optimal density of pupae in the volume of sand used (approximately $1.9 \mathrm{ml}$ soil/pupa). If too many larvae are added, those that cannot create pupation chambers will crawl back to the surface and wander the soil in an attempt to leave the container.

14. The pupation containers should be maintained at $25^{\circ} \mathrm{C}$, $>80 \%$ humidity and constant light for 1 week, followed by constant darkness for 13 days, until the adults begin emerging.

\section{Notes for pupation containers:}

- Use sandy soils when rearing SHB because sand is easier to sift through to expose and recover buried adult SHB if necessary. Most soil types will work; sand is easier to use. See Ellis et al. (2004c) for details.

- Soil should be discarded after one use or sterilized since there often is an increase in pupal mortality when unsterilized soil is reused.

- Never rely on wandering larvae to bury themselves naturally. If put on top of the soil, some larvae may not burrow into the ground for more than 2 weeks, thus widening the range of adult emergence. Manually-buried larvae emerge in a much narrower time period. Larvae will remain buried if the pupation containers are exposed to constant light. Wandering larvae may crawl to the soil surface if the containers are put in a dark room, thus widening the time range of adult emergence.

- Container depth (rather than width) appears to be important to pupation success.

15. Twenty days after burying the larvae in the pupation containers, fit the pupation containers with an inverted, similar container (adult beetle funnel trap) with a funnel pointing up into the mouth of the top container (Fig. 8).

The adult trap should be ventilated.

16. Loosely cover the funnel hole with a small strip of nylon mesh $(1 \times 3 \mathrm{~cm})$ that can be secured with tape.

Adult beetles emerging from the soil crawl through the funnel into the top container where they are unable to go back down. The nylon mesh discourages the adults from returning to the pupation container once they have entered the top container.

17. Spray a 1:1 mixture (by volume) of honey/water with a handheld pump sprayer through the ventilation holes into the container to feed the emerging adults.

Spray enough honey water to wet the side walls of the containers but not too much to promote pooling of the honey water on the bottom of the container.

18. Maintain the adults at $25^{\circ} \mathrm{C}$ and $>80 \%$ humidity under full light. The light encourages adults to move into the top container.

19. After $2-5$ days, more than $80 \%$ of the emerging adult SHB will

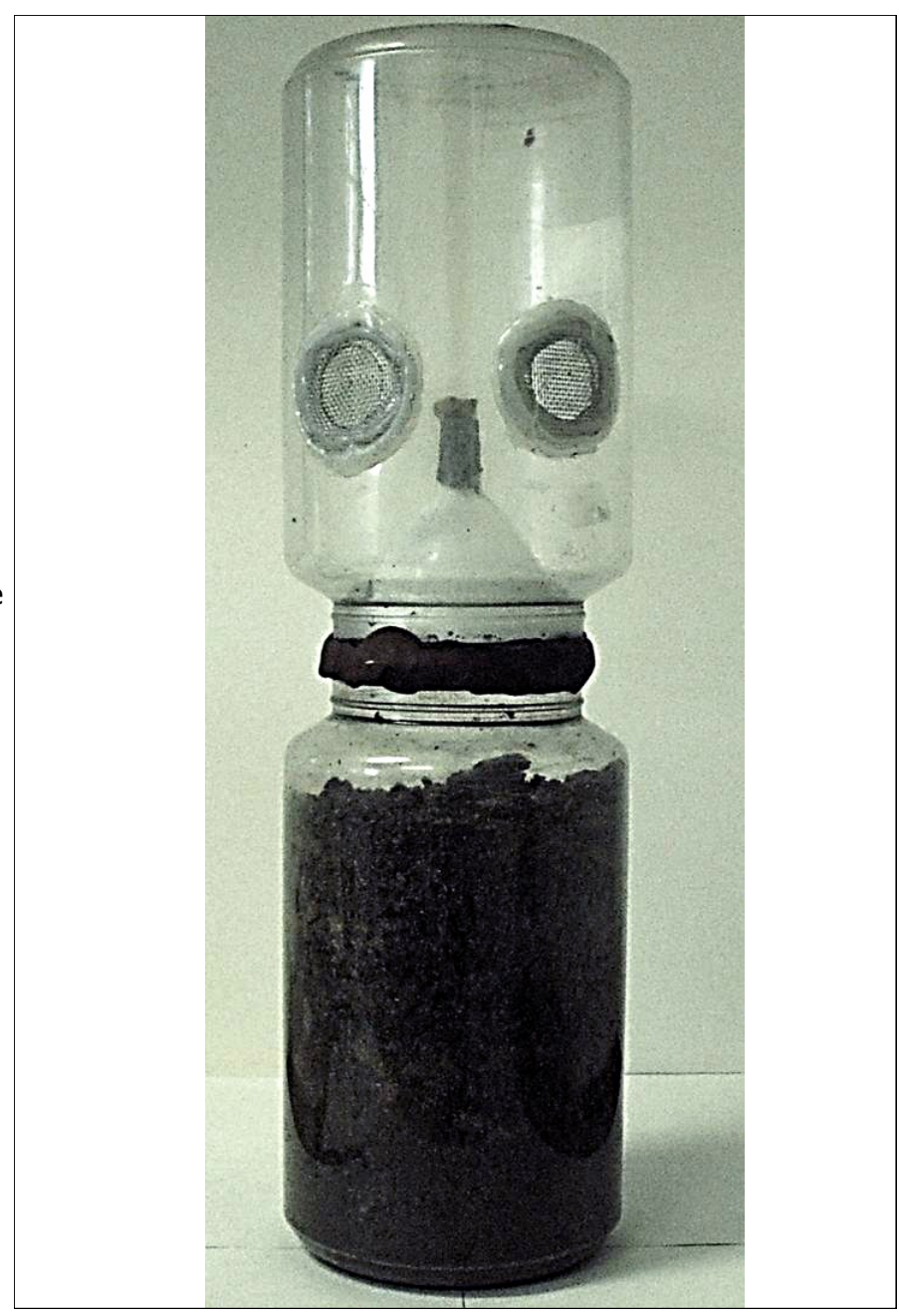

Fig. 8. Small hive beetle pupation chamber with an adult beetle funnel trap fitted on top. There is an inverted funnel in the middle that beetles from the pupation chamber (container with soil) crawl through to access the adult chamber (top). The adults can be fed with honey water that is sprayed through the ventilation holes in the upper container.

Photo: James Ellis.

be present in the top container. At this time, remove the funnel from the top container, invert the adult trap, and securely fasten its lid.

Since adult SHB often remain underneath the soil surface without emerging (up to 35 days, Muerrle and Neumann, 2004), they can be sifted out of the sand and collected using an aspirator. Adult SHB can be kept alive in these containers for more than 8 weeks by feeding them 1:1 honey water with a sprayer as previously described (see step 17).

Note: Since buried adult SHB can sexually mature before emergence, adult SHB may mate before emergence from the soil or before they are collected. Thus, rearing programs aimed at unmated adults should use the individual rearing approaches described below. 


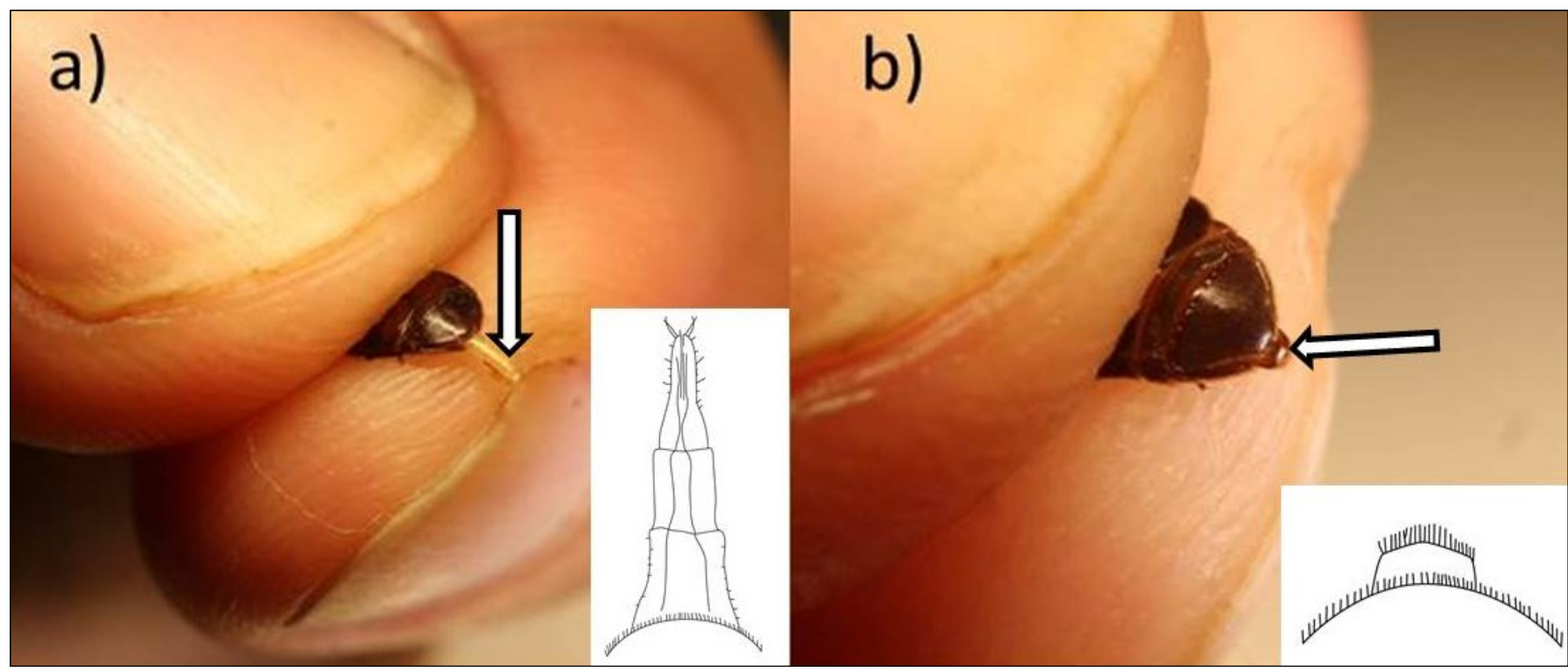

Fig. 9. Sexing of adult small hive beetles. Squeezing the abdomen will cause the female to extend her ovipositor (arrowed in $\boldsymbol{a}$.) and the male to protrude his 8th tergite (arrowed in $\boldsymbol{b}$.). The line sketches inset in both pictures are redrawn from Schmolke, 1974 and show the female ovipositor and male 8th tergite in detail.

Sketches: Kay Weigel (University of Florida); photos: Marc Schäfer.

\subsubsection{Individual rearing approach}

1. Fill standard $1.5 \mathrm{ml}$ Eppendorf ${ }^{\circledR}$ reaction tubes $1 / 3$ full with autoclaved pupation soil (see section 3.1.3.1.). Seal the tubes, place them in laboratory trays, and puncture the lids with a needle (3-4 small holes) to allow air circulation.

2. Collect wandering larvae from the rearing program (see section 3.1.3.1.).

3. Gently introduce an individual larva onto the soil of each tube using soft tweezers.

4. Cover the larvae with another $1 / 3$ full with autoclaved pupation soil (see section 3.1.3.1.).

5. Seal the tubes.

Follow instructions for storage conditions of trays in incubators until adult emergence (see section 3.1.3.1.).

6. Transfer adults, which have finished pupation (Fig. 3c), into new individual tubes.

7. Provide with $1: 1$ honey water ad libitum using a pipette.

The SHB can be maintained for up to 8 weeks in darkness at RT.

\section{Notes:}

If any other diet is used to rear or maintain SHB (e.g. to test reproductive success (Ellis et al., 2002b; Buchholz et al., 2008)), the food should be frozen first, especially if field collected (e.g. fruit) to kill any other insect eggs that may be present.

\subsubsection{Sex determination}

It is often required to determine the sex of individual SHB for experimental or monitoring purposes. SHB seem to have a female-biased adult sex ratio both in the field and in laboratory rearing approaches (field: USA:
Ellis et al., 2002a, Africa: Schmolke, 1974; Spiewok and Neumann, 2012; Australia: Spiewok and Neumann 2012; laboratory: Neumann et al., 2001a; Ellis et al., 2002b; Muerrle and Neumann, 2004).

\subsubsection{Sex determination of adults}

The easiest approach for adults has been developed by Schmolke (1974; Fig. 9).

1. Grasp the adult beetle so that the ventral side of the tip of the abdomen can be viewed.

2. Gently squeeze the beetle abdomen.

3. Squeezing the abdomen will cause the female to extend her ovipositor and the male to protrude his $8^{\text {th }}$ tergite (Fig. 9).

Females readily extend their ovipositor without much squeezing. If you are squeezing "hard" with little result, the beetle likely is a male. It is more difficult to cause male beetles to protrude their $8^{\text {th }}$ tergite so care must be taken to avoid harming the beetle.

If done gently, the sexed adults will not be affected adversely.

Note: When sexing many adult beetles (Ellis et al., 2002b; Spiewok and Neumann, 2012), it is recommended to slow them down by placing them in a fridge or in a vial on ice for at least $5 \mathrm{~min}$. (up to $10 \mathrm{~min}$.).

\subsubsection{Sex determination of pupae}

The sex of pupal SHB can be determined visually without the need to manipulate the individual (Fig. 10).

1. Observe the ventral side of the distal section of the abdomen.

2. Look for two bulbous projections on this location.

If present (Fig. 10a), it is a female pupa. These projections are absent in male pupae (Fig. 10b). 


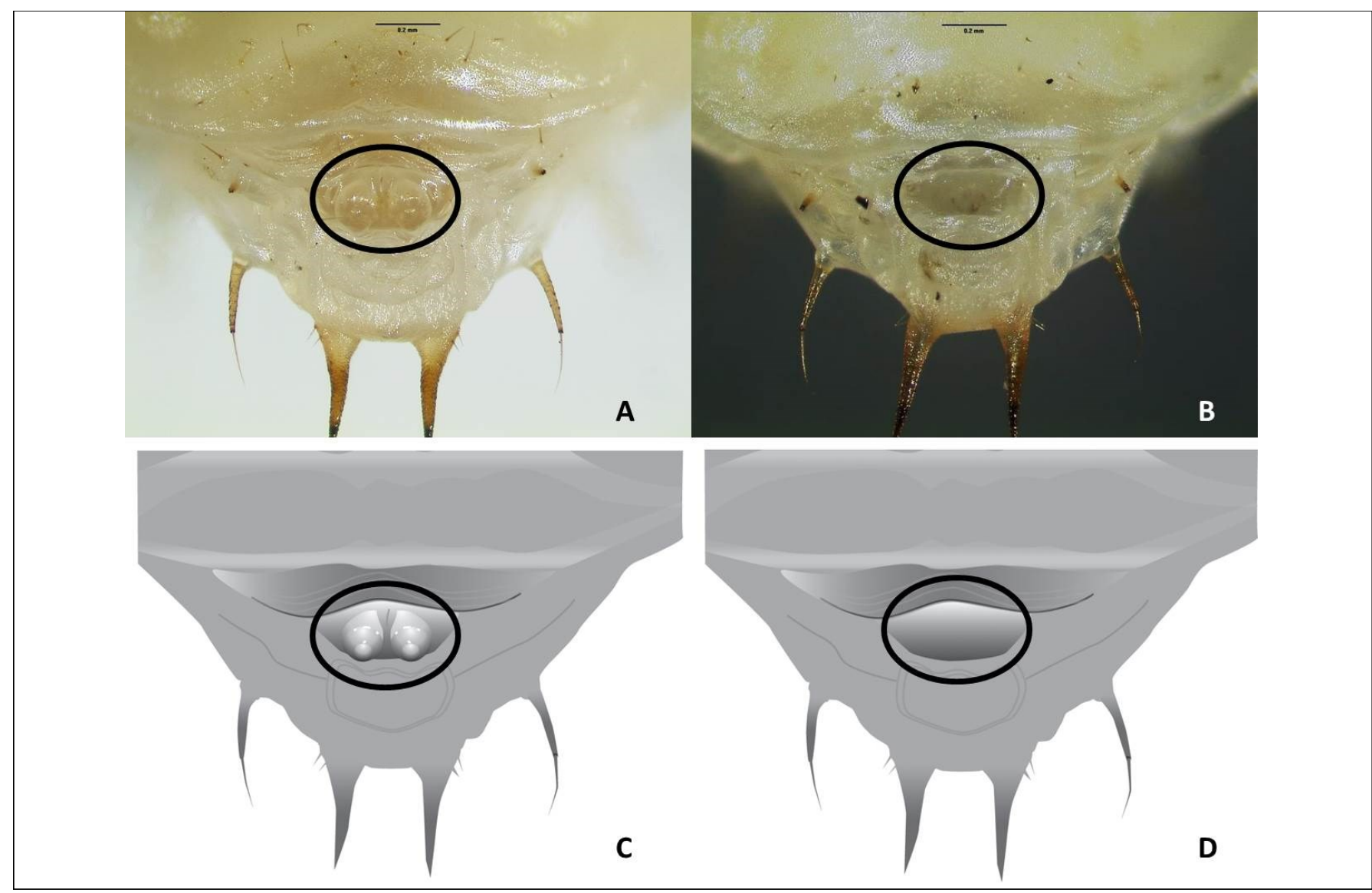

Fig. 10. Sexing pupal small hive beetles. $\boldsymbol{A}$. and $\boldsymbol{C}$. show the tip of the ventral side of the abdomen of a female small hive beetle. The two bulbous protrusions are circled. $\boldsymbol{B}$. and $\boldsymbol{D}$. show the tip of the ventral abdomen of a male small hive beetle. The bulbous protrusions are absent from the circled area. $\boldsymbol{A}$. and $\boldsymbol{B}$. are shown with enhanced contrast to highlight the genital area.

Sketches: Kay Weigel, University of Florida; photos Lyle Buss, University of Florida

\subsubsection{Marking techniques}

Experimental purposes often require cohort-specific or individual marking of SHB, e.g. for behavioural studies (see the BEEBOOK paper on behavioural methods by Scheiner et al., 2013). Therefore various marking techniques employing dyes, food colouring, dusting, and thoracic notching have been attempted in SHB larvae and adults with different levels of persistence and mortality.

\subsubsection{Marking SHB larvae}

Coloured food is a good method to mark SHB larvae.

1. Dissolve $1 \mathrm{~g}$ of the dye (Sudan Blue 670, Sudan M Red, Rhodamine B; S. Spiewok, unpublished data) in $9 \mathrm{~g}$ olive oil to obtain a stock solution.

2. Stir $3 \mathrm{~g}$ stock solution into $57 \mathrm{~g}$ honey.

3. Mix the honey with $90 \mathrm{~g}$ powdered pollen to obtain dyeconcentrations of $2,000 \mathrm{ppm}$.

4. Fill $10 \mathrm{~g}$ of the coloured food into small containers with lids ventilated with tiny holes that allow airflow but prevent escape of SHB larvae.
5. Place 10 young larvae (see section 3.1.3.1.) into each container and incubate for 8 days at $30^{\circ} \mathrm{C}$ till they reach the wandering stage.

6. Wandering larvae fed with Sudan Blue 670 will show green colouration. Sudan M Red results in reddish and Rhodamine B in violet coloured larvae.

Note: Feeding SHB larvae with food colours showed no decent results in the adults after metamorphosis (S. Spiewok, unpublished data).

\subsubsection{Marking adult SHB}

\subsection{Feeding adult SHB with coloured food}

1. Dissolve the dye (Rhodamine B, green and blue food colouring; S. Spiewok, unpublished data) in sugar water (40\%).

2. Allow recently emerged, unfed SHB adults to feed for 3 days ad libitum.

Note: After two weeks in field colonies, SHB fed with green and blue food colouring were distinguishable from other SHB, but both colours 
came out turquois (S. Spiewok, unpublished data). Rose Bengal, fed to bees, was used successfully to identify the feeding interactions between SHB and honey bees (Ellis et al., 2002c) but resulted in high mortality when fed to SHB directly (S. Spiewok, unpublished data).

\subsection{Thoracic notching of adult SHB}

For capture-mark-recapture studies of adult we recommend thoracic notching, as notched beetles (Fig. 11) survived and resulted in a high rate of recovery (de Guzman et al., 2012).

1. Hold the SHB between two fingers under a stereo microscope.

2. Carefully notch the edge of either the right or left margin of the SHB's pronotum (Fig. 11) using the tip of an iris scissor ( $8 \mathrm{~mm})$

Note: With double notches or different cutting angles, individual marking may also be possible. De Guzman et al. (2012) also tested the use of blue and red chalk dusts to mark SHB, but this was not persistent and caused high mortality. For specific details please refer to the original publication.

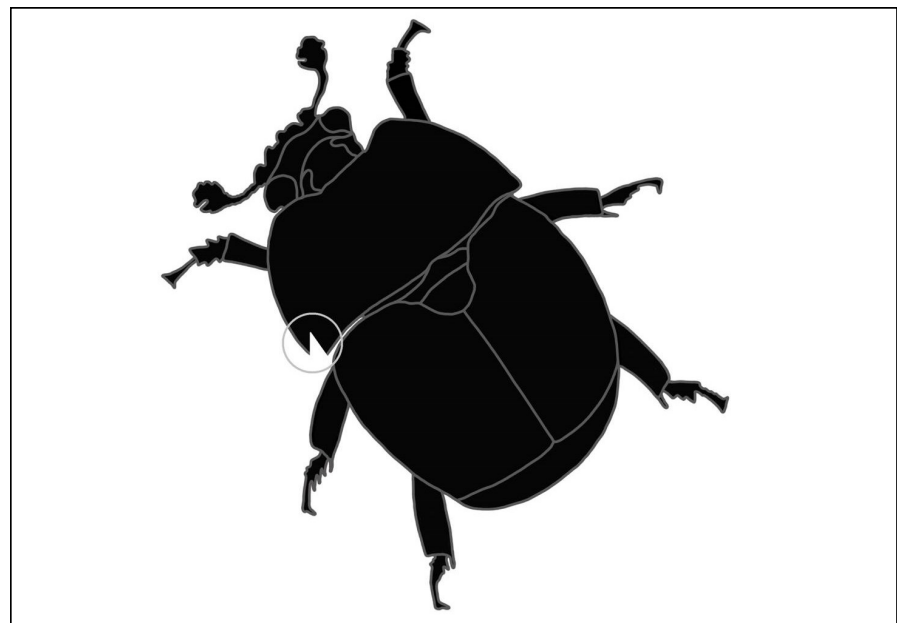

Fig. 11. Adult SHB marked by thoracic notching.

Drawing: FLI

\subsubsection{Effect of external conditions on SHB in the laboratory}

\subsubsection{Investigating diet effects on SHB reproduction}

SHB feed on honey, pollen, and bee brood in honey bee colonies. However, they have been shown to reproduce on other diets as well (Ellis et al., 2002b; Buchholz et al., 2008). Below, we outline a method for investigating diet effects on SHB reproduction modified after Ellis et al. (2002b).

1. Laboratory rear (see section 3.1.3.2.) and sex (3.1.4.) adult male and female beetles individually to ensure that mating occurs only in the food containers. In reproduction studies, it is essential to know the ratio of males and females. Only use $>1$ week old adults to ensure their reproductive maturity.

2. Place a SHB couple (one female and one male) into a plastic container (Fig. 12).

The container lids should contain small holes to allow sufficient ventilation.
3. Prepare at least 10 containers of beetles (10 replicates) per diet tested.

4. Add an appropriate amount of diet per adult container to accommodate the amount of offspring that will be produced. Unfortunately, there is no established formula for the volume of food that should be added given an established number of adult beetles. The investigator will have to experiment with this since this is an important consideration. For example, SHB adults reproduce explosively on bee brood but considerably less so on fruit. Therefore, larvae can quickly exhaust food resources in some circumstances. The diet should be frozen first, especially if field collected (e.g. fruit) to kill any other insect eggs that may be present.

5. Move adult beetles from the food chambers to new ones every 3-4 days to alleviate problems associated with explosive population growth on limited food resources, if necessary.

Limiting the amount of time adults spend in a given container equally limits the number of eggs female beetles will be able to oviposit in the container, thus lessening the likelihood that food will be rapidly exhausted by larvae. This way, adults can be moved from container to container throughout their reproductive lifetime.

6. Monitor the containers daily to ensure that the beetles always have food available (only in case of ad libitum studies, otherwise adjust accordingly, e.g. let SHB starve).

In reproduction studies, larvae should be able to feed ad libitum if one is determining how diet impacts the number of larvae produced and amount of time it takes the larvae to reach the wandering phase.

7. Once larvae in the diet container reach the wandering phase, empty the diet and larvae into a metal tray to facilitate capture (see section 3.1.3.1.).

8. Place wandering larvae in soil pupation containers (see section 3.1.3.1.).

9. Keep all rearing containers at $25^{\circ} \mathrm{C}$ and $>80 \%$ humidity for one week under light and then until adult emergence under dark conditions (see section 3.1.3.1.).

10. Determine reproductive success. Reproductive success is defined by Ellis et al. (2002b) collectively as the total number of offspring produced per female on a given diet (determined by counting the number of larvae produced in all of the food containers assigned to the adult pairs) and the percentage of those offspring that pupate successfully (= live adult SHB). One may also look at the reproductive capacity of the $\mathrm{F} 1$ generation for further evidence of reproductive success.

\section{Notes:}

- Allowing SHB adults to reproduce on wet or sticky diets is of special concern because the adults can drown in the food if it becomes fermented and begins to pool in the container. In these instances, it is advisable to place a piece of paper towel in the bottom of the container to absorb moisture. 
- Larvae maturing on wet or sticky diets cause the container environment to become inhospitable in many instances. So, these containers should be well ventilated (with holes that larvae cannot traverse) to facilitate airflow and checked 2-3 times daily for any problems or inconsistencies.

- Field-collected adult beetles are not suited for determining maximum reproductive capacity because their age and mating status at the time of collection is not known and they may have already reproduced prior to the experiment.

- Manipulations with adult beetles should be done under insect nets to minimize beetle escape (see section 3.1.).

- The rearing containers should be provisioned with water (moistened cotton balls (Fig. 12) similar to maintain adult bees in cages see respective BEEBOOK paper Williams et al., 2013), especially when the adults are attempting to reproduce on a dry food (such as pollen).

- Freezing the diet to kill eggs of other insects potentially present will alter its microbial balance. This could alter the diet's nutrition or attractiveness to SHB.

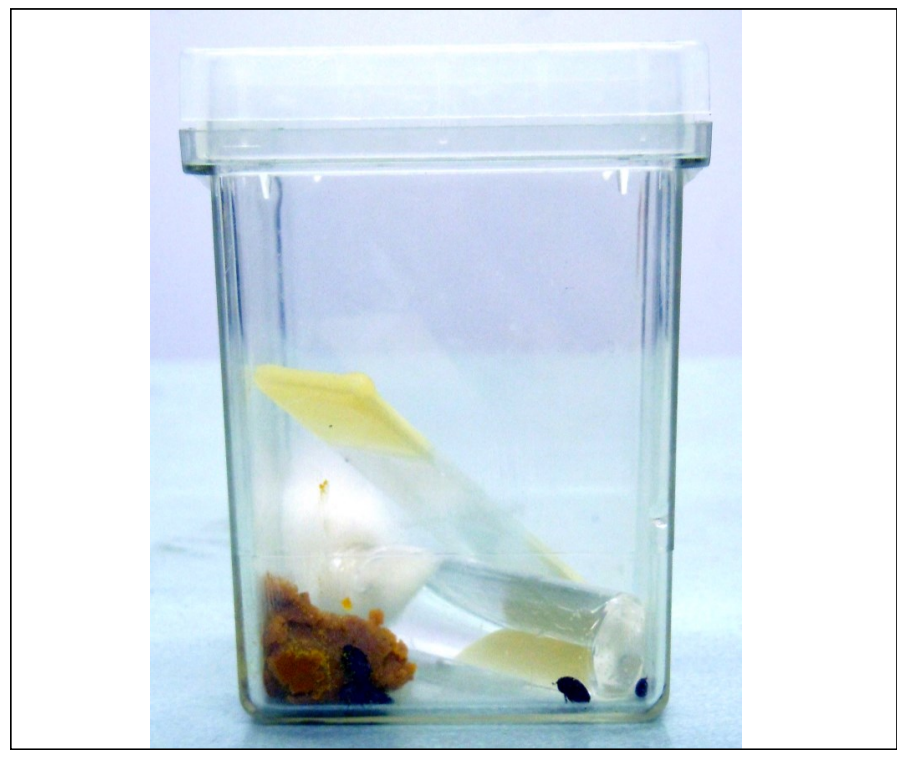

Fig. 12. Plastic container for maintenance of adult SHB (Photo: Elise Jeanerat) with standard food ad libitum (see section 3.1.1.1. pollen, honey, and a honey bee protein supplement in a 1:1:2 volume ratio), tap water in a small glass vial sealed with a piece of cotton wool to prevent draining, and two microscope slides as oviposition site (see section 3.2.4.). Food and equipment can be adjusted according to experimental needs (e.g. fruits instead of standard food and two or no oviposition sites).

\subsubsection{Determining soil effects on SHB pupation}

Ellis et al. (2004c) determined the impact of soil type, moisture, and density of SHB pupation success see section 3.1.3.1.). The methods they used are applicable to any study focusing on pupation habits of SHB.
1. Autoclave test soils prior to use to kill pathogens.

2. The soil moisture can be manipulated by first drying the soil in an oven.

2.1. Spread the soil in a shallow, metal tray to facilitate drying. The drying oven can be set to $85^{\circ} \mathrm{C}$. The soil is "dry" when the tray holding the soil no longer loses weight over a $24 \mathrm{~h}$ period. This takes 6 weeks or longer at $85^{\circ} \mathrm{C}$. If decomposition of organic soil compounds is of concern to the research, the soils can be dried at lower temperatures for longer periods of time.

2.2. Measure soil moisture as water by weight (either a dry mass or wet mass basis). For the dry mass gravimetric method, soil moisture $=$ grams of water/grams of dry soil.

2.3. Using this formula, create soils of various moistures by first drying the soil as outlined above, weighing it, and then adding an appropriate amount of distilled water to create the desired water by weight moisture level.

3. For each soil type of interest, place a desired amount of loose soil into plastic pupation containers (pupation chambers are better if they are tall rather than wide).

Ellis et al. (2004c) used cylindrical containers that were $\sim 22 \mathrm{~cm}$ in height and $1,000 \mathrm{ml}$ in volume. The containers should have small holes drilled in the bottom to allow water to exit.

4. Compact the soil while in the pupation chamber if soil density is an important component of the study.

4.1. Run 1 I of distilled water through the soil-filled pupation container.

The holes in the bottom of the container will allow the water to drain. The water compacts the soil naturally.

4.2. If a predetermined amount of water by weight is desired in the packed soil, dry the packed soil while in the pupation container.

The oven must be set at a temperature that does not melt or distort the plastic container, or decompose soil compounds/ nutrients (for the microbes, not the beetles themselves) if that is of interest. The container of soil must remain in the oven until it no longer loses weight over a $24 \mathrm{~h}$ period.

4.3. Add the appropriate amount of distilled water to the dried, packed soil to achieve the desired water by weight moisture.

5. Place wandering SHB larvae produced according to standard rearing procedures (see section 3.1.3.1.) in the pupation containers once the soils are conditioned to need.

\subsubsection{Transmission of bee pathogens by small hive beetles}

Similar to other pests, SHB may act as vectors of honey bee pathogens (AFB: Schäfer et al., 2010b; viruses: Eyer et al., 2009a, b). This section describes experimental methods to investigate such pathogen transmission by SHB. 


\subsubsection{Investigating potential interactions between A.} tumida and Paenibacillus larvae, the causative organism of American foulbrood

Brood combs with clinical American foulbrood (AFB) symptoms can be used to contaminate larval and adult SHB in the laboratory (Schäfer et al., 2010b). This contamination was shown to persist in pupae and newly emerged adults. Contaminated adult SHB can be used to expose honey bee field colonies with $P$. larvae spores. The corresponding methods are outlined below:

1. Take clinical combs with sealed and unsealed brood from infected AFB colonies and arrange into plastic containers with an equal amount of infected brood cells each.

2. Collect adult SHB from rearing programs or from infested field colonies and introduce into the containers $(\mathrm{N}=20)$.

3. Keep the containers in darkness at $30^{\circ} \mathrm{C}$ and high relative humidity (> 50\%).

4. After seven days, collect contaminated adult small hive beetles.

5. Three days later, collect wandering larvae.

Both adults and larvae can be used depending on the needs of the experiment. If needed, larvae can be moved into sand containers placed in darkness in an incubator to allow further development (see section 3.1.3.).

6. To quantify the number of $P$. larvae spores per specimen (see respective BEEBOOK paper by de Graaf et al., 2013), immediately freeze the samples after collection.

7. To expose field colonies to contaminated adult SHB, introduce the collected beetles into the experimental field colonies, which should be free of $P$. larvae spores.

Note: Please always consider the biosafety risks when manipulating $P$. larvae for research! (see the BEEBOOK paper on American foulbrood by de Graaf et al., 2013). This method might also be practicable for European foulbrood and other brood diseases.

\subsubsection{Investigating the potential of SHB to vector honey bee viruses}

To investigate the potential of SHB as a vector of honey bee viruses, SHB can be fed with virus-infected workers or brood or with viruscontaminated wax or pollen. Eyer et al. $(2009 a, b)$ found no virus infections through feeding of contaminated pollen, but SHB became infected through feeding on infected worker or brood and on contaminated wax:

1. Maintain laboratory-reared adult SHB (see section 3.1.1. and Fig. $8 \& 12$ ) and provide virus contaminated food or other material.

2. Collect adult SHB after 6 days and store adequately until virus analysis (see respective BEEBOOK paper by de Miranda et al., 2013).

\subsubsection{Investigations of SHB pathogens and parasites} Knowledge about pathogens and parasites of SHB may offer alternative avenues for pest control and will in general contribute to our understanding of this species.

\subsubsection{Inoculating SHB larvae with entomopathogenic fung} Fungal infected cadavers (Ellis et al., 2004e) or conidial suspensions (Muerrle et al., 2006) can be used to infect SHB. Ellis et al. (2004e) achieved about $30 \%$ mortality among pupating beetles exposed as wandering larvae to beetle cadavers from which Aspergillus flavus and A. niger were isolated (see BEEBOOK paper by Jensen et al., 2013):

1. Collect healthy-looking wandering SHB larvae produced using autoclaved soil and the rearing method (see section 3.1.3.).

2. Place desired amount of wandering larvae in a small plastic container $(11 \times 11 \times 9 \mathrm{~cm})$ that has SHB larvae/pupae that show signs of being infected with a fungal pathogen (Ellis et al., 2004e). It is important to confirm that the cadavers are carrying the pathogen of interest using adequate microbiological techniques (Mürrle et al., 2006 and the respective BEEBOOK paper (Jensen et al., 2013)).

3. Allow the healthy larvae to wander in the container among the cadavers for 24 hours.

4. After 24 hours exposure to infected cadavers, place the wandering larvae in soil pupation chambers and allow to pupate (see section 3.1.3.).

\subsubsection{Infesting SHB with nematodes}

This method to infest SHB with nematodes was developed by Ellis et al. (2010). It allows for the testing of a variety of nematode species aiming at alternative control of SHB.

\subsection{In vitro infestation of wandering larvae with an aqueous suspension of nematodes}

Nematode infective juveniles (IJs) often are suspended in water by the company from which the nematodes are obtained. It is such suspension that the following method is based on to infest SHB larvae.

1. Place a piece of filter paper in the bottom of a petri dish. The filter paper should cover the bottom of the dish entirely.

2. Determine the density of IJs suspended in the water solution.

3. Add the desired number of IJs to the filter paper using a pipette. One should gently invert the container of IJs to ensure even dispersal of nematodes throughout the liquid. The total volume of water including the suspended IJs added to the filter paper should be $1.5 \mathrm{ml}$.

For example, suppose that you are trying to infect wandering beetle larvae with 200 IJs per larvae. If you plan to add 10 beetle larvae to the petri dish, you will need to add 2,000 IJs 
to the dish. If you determine that there are 2,000 IJs per $0.5 \mathrm{ml}$ of water, pipette $0.5 \mathrm{ml}$ of the water/nematode suspension and $1 \mathrm{ml}$ of distilled water to the paper for a total of $1.5 \mathrm{ml}$ solution added to the paper.

4. Add desired number of wandering SHB larvae to the petri dish.

5. Replace the lid to the petri dish and secure the lid to the bottom using a tight rubber band. SHB larvae can push up the lid of a petri dish and escape so a rubber band is necessary to keep this from occurring.

6. Place the dishes in an incubator at $25^{\circ} \mathrm{C}$ and no light.

7. Assess mortality in the SHB larvae at any time period though resolution is greater the more often one views the dishes.

8. Experimental controls include adding nothing to the dish (no paper, water or nematodes), adding only filter paper, adding only $1.5 \mathrm{ml}$ of distilled water, or adding filter paper and $1.5 \mathrm{ml}$ of distilled water.

\subsection{In vitro soil infestation of larvae using a sand}

\section{bioassay}

This method is similar to that presented above.

1. Rather than using filter paper in the petri dish, use $30 \mathrm{~g}$ of dried autoclaved sand.

2. Pipette the aqueous nematode suspension directly onto the sand, which is then wetted to about $10 \%$ water by weight.

3. Add wandering SHB larvae to the petri dish.

4. Replace and secure the top.

5. Place the dishes in an incubator at $25^{\circ} \mathrm{C}$ and no light.

6. Assess mortality in the SHB larvae at any time period though resolution is greater the more often one views the dishes.

7. Control petri dishes include adding nothing to the dish (no sand, water or nematodes), adding only sand, adding only $1.5 \mathrm{ml}$ of distilled water, or adding sand and $1.5 \mathrm{ml}$ of distilled water.

\subsection{In vitro soil infestation of pupae with an aqueous suspension of nematodes}

1. Autoclave soil.

2. Moisten soil to $10 \%$ water by weight.

3. Place autoclaved soil in small plastic cups.

Ellis et al. (2010) used $118 \mathrm{ml}$ cups. A similar size is appropriate.

4. Place 5 wandering SHB larvae in the soil cups and allow them to bury themselves and begin the process of pupating.

5. Two days after the addition of larvae, pipette the desired amount of IJs suspended in an aqueous solution onto the soil in the cup.

6. Add $5 \mathrm{ml}$ of water to the soil cups every 3-4 days as needed to maintain adequate soil moisture.

7. Place the cup lids on the cups to enclose the SHB.

One can expect the SHB in the control cups (no nematodes) to begin to emerge as early as day 17 post addition to the soil.

\subsection{In vitro soil infestation of pupae with nematode- infected cadavers}

Follow the method outlined in section 3.1.8.2.3. with one modification at step 5 .

5. Rather than applying nematodes via aqueous suspension, add a SHB cadaver infected with the target nematode to the cup. Bury the cadaver about $0.5 \mathrm{~cm}$ below the soil surface. The cadaver can be produced according to the method outlined in section 3.1.8.1.

Notes:

- The methods outlined can be scaled up and modified for field use.

- Ellis et al. (2010) did this by burying the soil cups outside. The cups had screened lids and bottoms to allow rain drainage through the cups. Otherwise, nematodes and SHB larvae were added to the cups as in the in vitro assays. The methods also can be used to determine the generational persistence of the nematodes. This is accomplished by adding 5 additional SHB larvae to the soil cups weekly. If the nematodes are reproducing and moving into the newly-burrowing larvae, adult SHB emergence rates in the soil cups will be perpetually low.

\subsection{Field techniques}

The described field techniques involve a wide range of different protocols for investigations including interactions between honey bees and SHB, behavioural studies, quantification of SHB in colonies and more general techniques such as the introduction of SHB into honey bee colonies.

\subsubsection{Investigating intra-colonial interactions between adult bees and adult SHB}

SHB and adult worker honey bees interact with one another regularly within a colony (see Elzen et al., 2001; Neumann et al., 2001c; Ellis 2005; Ellis and Hepburn, 2006; Ellis et al., 2003c, d; 2004a, b; Pirk and Neumann, 2013). Most of the studies on bee/beetle behavioural interactions have been conducted using honey bee colonies hosted in observation hives (see the BEEBOOK paper on behavioural methods, Scheiner et al., 2013). To that end, we discuss initial experimental establishment and then various methods that can be used to investigate a suite of beetle/bee interactions. The series of procedures outlined below likely are amendable for use by those investigating the interactions between adult bees and larval SHB.

\subsubsection{General experimental establishment}

1. Establish equalized 3-frame observation hives (see the respective BEEBOOK paper Delaplane et al., 2013) according to the parameters set for the study (one brood frame and two 
honey frames; queenright or queenless, etc., see the BEEBOOK paper on behavioural methods by Scheiner et al., 2013 for details on establishing and maintaining observation hives) and remove any beetles currently living in the colony using aspirators (see Fig. 6).

2. The observation hives should be kept in a dark room, with no outside or artificial light shining on the hive.

3. According to the needs of the experiment, collect adult SHB from rearing programs (see section 3.1.3.) or from infested field colonies. The beetles can be all males, all females, agecohort specific, etc. per the needs of the experiment. Adult beetles should be sexed if required (see section 3.1.4.) and introduced into the observation hives after dusk, the preferred time window for SHB flights (Neumann et al., 2012).

4. Hives should be monitored at least twice daily (Neumann et al., 2001c; Ellis et al., 2003c, d, 2004a, b) at time windows suitable for the experimental needs (morning and afternoon or only after local dusk for nocturnal behaviour). All night observations of the hives should be done using red lights to minimize behaviour disturbance to colonies. It may be necessary to use a small flashlight to find beetles confined in particularly hard-to-view areas. The order of observed hives should be altered at a daily basis at each time window.

5. During behavioural studies, it is essential to precisely define the behavioural categories/pattern. They have to be clearly defined and distinct; under no circumstance should the observer come into the situation that a certain observed behavioural pattern could be either behaviour 1 or behaviour

2. As a hypothetical example let's assume that two categories are labelled "walking" and "running". These categories would be examples of poorly defined behaviours, since they do not give a clear objective definition. The categories "walking,

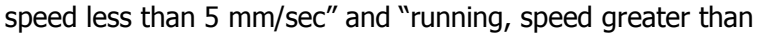
$5 \mathrm{~mm} / \mathrm{sec}^{\prime \prime}$ would be clearly defined and are distinct. As another hypothetical example, the categories "feeding" and "trophallactic interactions" would be not helpful category choices since they overlap.

6. In most behavioural studies, it is important to know where the interaction took place, especially in a social insect colony like a honey bee colony and especially in the case of SHB/honey bee interactions. Therefore, it is useful to superimpose a transparent grid of squares onto both side windows of an observation hive to fix the location of the interaction. Obviously, the size of the square determines the spatial resolution. The general consensus is to use $5 \times 5 \mathrm{~cm}$ squares (Moritz et al., 2001; Neumann et al., 2001b, 2003; Ellis et al., 2003d), which then could be even further subdivided with slightly drawn internal $1 \times 1 \mathrm{~cm}$ squares (Ellis et al., 2003d). One has to avoid overloading the side windows with markings to ensure that one can actually observe the behaviour. The labelling of the rows and columns should be included on the edge of the grid. To avoid confusion, the rows should be labelled with numbers and the columns with letters (or vice versa). It is highly recommended when preforming observations on both sides of an observation frame to continuously label the columns around both sides. For example with a $6 \times 9$ grid on each side, the rows are labelled 1-9 and the columns are labelled A-F on one side and G-L on the opposite side.

7. At each observation period, the observer should screen the colony in a left-to-right pattern, following the uppermost $5 \times$ $5 \mathrm{~cm}$ bold square. This pattern should be followed with the second row of $5 \times 5 \mathrm{~cm}$ bold squares, continuing to the bottom of the grid. This observation pattern minimizes the chance that the same area will be viewed more than one time and that behaviour will be double counted. Both sides of the observation hive should be monitored this way.

\subsubsection{Behavioural categories}

The following behavioural categories are a synthesis of the numerous studies (Elzen et al., 2001; Neumann et al., 2001c; Solbrig, 2001; Ellis 2005; Ellis et al., 2002c; 2003c; 2004a, b; Pirk and Neumann 2013) and can be used to investigate interactions. The following behavioural categories were defined:

\section{SHB:}

Resting/Ignore (within $5 \mathrm{~mm}$ of a honey bee) - not moving at all, none of the other categories can be observed.

Walking - moving around $(<5 \mathrm{~mm} / \mathrm{sec}$. without being chased by a SHB or worker).

Running - moving fast ( $>5-10 \mathrm{~mm} / \mathrm{sec}$.), without being chased by a SHB or worker.

Flee - moving fast ( $>5-10 \mathrm{~mm} / \mathrm{sec}$.), while being chased by a SHB or worker.

Being chased - a) by fellow SHB, b) by a worker c) by more than one worker.

Mating - male is mounting the female

NOTE: in this definition of the behavioural category mounting is used as a proxy for mating.

Feeding on - a) pollen store, b) nectar store, c) larvae, d) a dead honey bee worker, e) a dead SHB, f) a live honey bee worker.

Antennating with a SHB - antennal contact with one or more a SHB. Antennating with a honey bee worker - antennal contact with any bee e.g. with a guard bee (guarding the entrance of the hive (Rösch, 1925) or at a confinement site or prison (Neumann et al., 2001c; Ellis, 2005)).

Trophallactic contact with worker bee - obtaining a drop of food from a bee that is presenting food between its mandibles. 


\section{Interfering with other SHB in trophallactic contact with}

worker bee - obtaining food while another SHB gets fed.

Turtle-defence posture - stays motionless and tucks its head underneath the pronotum with the legs and antennae pressed tightly to the body.

Mount a bee - mounting the workers' abdomen and cutting with the mandibles through the tissue between the tergites.

\section{Honey bees:}

There are more than 50 behavioural categories described for honey bees (see for example Kolmes, 1985; Neumann et al., 2001b; Pirk, 2002). The following state only the basic ones related to SHB:

Resting/Ignore (within $5 \mathrm{~mm}$ of a SHB) - not moving at all, none of the other categories can be observed.

Walking - moves around at $<1 \mathrm{~cm} / \mathrm{sec}$.

Running - moves around at $>1 \mathrm{~cm} / \mathrm{sec}$.

Chasing - running and following an intruder (SHB).

Biting - mandibles are open and the bee tries to bit and grab the SHB.

Stinging - bends the abdomen to bring the stinger into position and/or sting is moving in and out of the sting sheath .

Trophallactic interaction with/feeding - a) another worker, b) queen, c) confined or SHB, d) one free running SHB - the worker regurgitates a droplet from its honey stomach, which can be observed between the mandibles and from which one or more food receivers will feed (SHB or bees).

Guarding - a worker prevents a SHB from moving freely by keeping it at bay in a crack or a prison/confinement. This kind of pattern is often followed by feeding and/or biting.

Building prison (confinement) - chewing or/moulding the waxpropolis mixture constituting the barrier of the prison (confinement).

Final note: All categories can be further subdivided or merged depending on the needs of the experiment.

\subsubsection{Investigating behavioural interactions of adult honey bees and adult SHB at the colony entrance - two alternative options}

Option 1 - at the entrance:

Two methods have been developed to investigate adult bee and SHB (or other nest invader) interactions at the hive entrance (Halcroft et al., 2011; Atkinson and Ellis, 2011a):

1. Build a modified observation hive to facilitate nest entrance observation.

The entrance corridor to the hives should contain a test arena (Atkinson and Ellis, 2011a, used a test arena of $10 \times 20 \mathrm{~cm}, \mathrm{~L} \times \mathrm{W}$ ), with a floor marked with a $1 \mathrm{~cm}^{2}$ grid system (Fig. 13 and 14).

2. Build a closable partition at both ends of the test arena using acrylic glass or another material. Pierce the acrylic glass with holes to accommodate normal airflow into and out of the hive.

3. Build a side entrance to the test arena through which beetles can be introduced (Fig. 13 and 14).

4. Conduct the trials under red light conditions to take into account usual SHB flight activity after dusk (Neumann et al., 2012).

5. Close both doors to the test arena to "trap" guard bees in place in the nest entrance. The doors should be closed slowly and with minimum disturbance in order to not excite the guard bees.

6. Introduce, for each trial, one adult SHB through the side entrance of the test arena.

7. Insert likewise a glass bead into the test arena as a control. The bead should be roughly the same size and colour as the invader. Atkinson and Ellis (2011a) tethered a $60 \mathrm{mg}$ black bead to a $15 \mathrm{~cm}$ piece of monofilament fishing line so that the bead could be retracted from the test arena after the observation period.

8. Once introduced, record the responses of guard bees to the beetle or glass bead for any length of time though Atkinson and Ellis (2011a) recorded responses for $60 \mathrm{sec}$.

9. Three potential guard bee responses can be recognized (perhaps more can be discovered using this method):

- Ignore (a bee's head comes within $5 \mathrm{~mm}$ of the subject but without making contact),

- Contact/interacting (the bee physically contacts the subject in a non-defensive manner, which involves licking of the beetle and antennating), and

- Defend (the bee attempts to sting and/or remove the subject from the nest, Elzen et al., 2001, see section 3.2.1.2. on behaviour)

In the event that the test arena is not sealed well enough to prevent beetle escape, only trials in which the beetles remain in the arena for $\geq 30 \mathrm{sec}$. should be counted.

10. After the observation period, open the acrylic glass doors on either side of the test arenas for $>10 \mathrm{sec}$. to allow movement of honey bees into/out of the central nest area and to reduce guard bee agitation.

11. Allow time between trials for the beetles to naturally exit the test arena or for the bead to be withdrawn. In Atkinson and Ellis (2011a), the average time between trials was > $1 \mathrm{~min}$.

12. Use test beetles and beads only once.

13. It is common to trap different numbers of guard bees in the test arena for each trial and colony when following this method. Consequently, convert bee responses to beetles or beads to proportional data to facilitate fair data comparison across trials. Atkinson and Ellis (2011a) state that this is not the proportion of bees performing a given response but rather the proportion of all responses that were Ignore, Contact, and 
Defend responses. This way, a single bee may demonstrate these behaviours multiple times throughout the observation period and the behaviours be counted.

14. Analyse data as outlined in the statistical guidelines of the BEEBOOK (Pirk et al., 2013).

Note: Trials should be conducted using multiple observation hives and simultaneously if resources permit. The latter allows one to minimize observation period and weather impacts on behaviour at the nest entrance.

\section{Option 2: T-shaped arena entrances in an observation hive}

This option was developed in the Social Insect Research Group at the University of Pretoria (Strauss, 2009). The advantage is that it does not interfere with the ongoing foraging activity of the colony and utilizes the observation, that any given natural colony often has more than one entrance. It further allows the manipulation of the intruder, in this case SHB, without having the risks of releasing guard bees. The T-shaped form (Fig. 13) offers two chambers to introduce intruders from more than one position and prevents any line of sight between the guards and the intruder before the experiments starts.

1. Attach the T-shape container to the hive.

2. Give at least three days for the guard bees to recognize the additional hive entrance.

3. Cover the arena with a glass lid to allow for observations and to prevent SHB and honey bees from escaping.

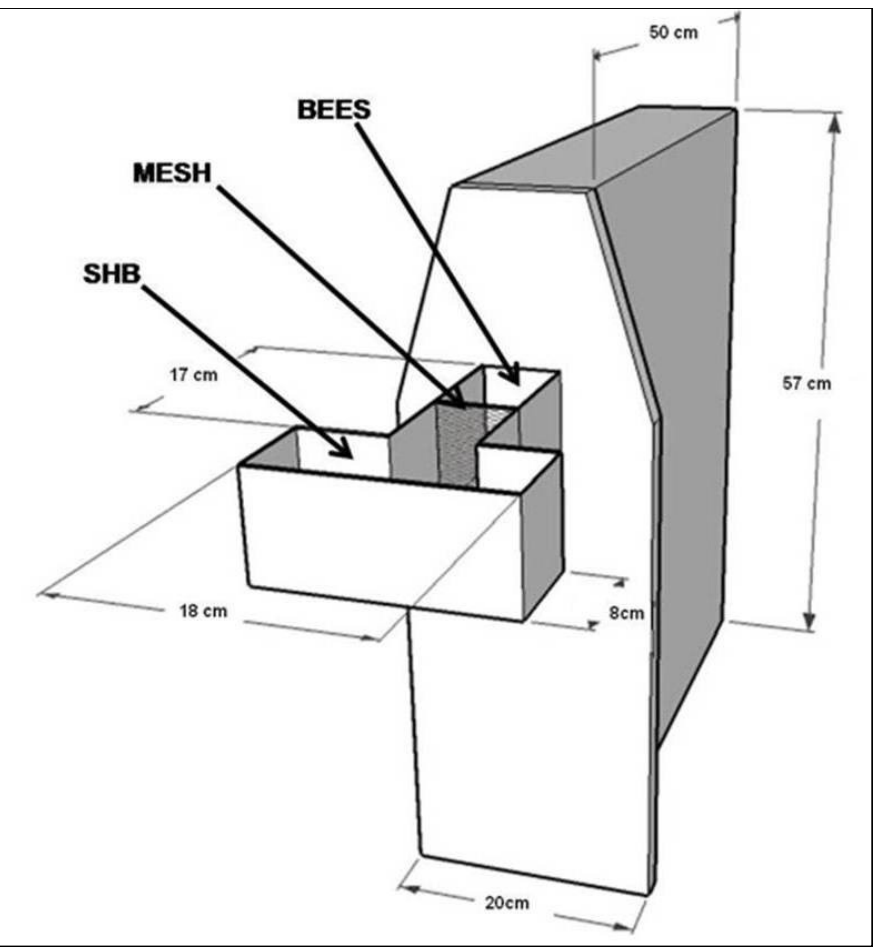

Fig. 13. Observation hive with $\mathrm{t}$-shaped container as a testing area attached to it. Figure with permission from the author.

Drawing: Ursula Strauss
4. Superimpose a grid on the glass if spatial information has to be recorded (see section 3.2.1.1.).

5. Insert a piece of metal mesh $( \pm 9.5 \times 4.9 \mathrm{~cm})$ into the wooden box as a barrier to separate the intruder/SHB and honey bees. Instead of wood also polycarbonate could be used (Köhler et al., 2013). Holes in the mesh are only large enough for SHB to move through, thereby preventing honey bees from moving into the part of the container where the SHB were released. In this design, SHB have access to both the hive and container whereas honey bees only have access to the hive and the part of the container closest to the hive entrance.

6. To optimize the observations and to reduce the influence of the observer, record the interactions using a remotely controlled CCTV system.

The recorded footage can be analysed using software designed for behavioural studies.

Advantage of option 2 is that the setup is not interfering with the gas exchange of the colony, normal activity is unaffected, and therefore observations during the day are possible. In addition, ample of space for the observer or additional equipment is available, so one does not have to squeeze between the exit hole and the observation hive.

Note: Depending on the questions asked both options have their advantages or disadvantages. If one needs constant flow of foragers coming into contact with the SHB option 1 might be better. If the experiment should not interfere with the normal activities of the colony option 2 might be more suitable.

\subsubsection{Investigating SHB oviposition behaviour and bee hygienic responses to SHB eggs and young larvae}

Adult SHB females will oviposit in cracks and crevices around the honey bee nest (Fig. 1, Lundie, 1940; Neumann and Härtel, 2004). Occasionally, the females will bite holes in the capping and/or side of brood cells, insert their ovipositor into the hole, and oviposit on the bee developing in the cell (Ellis et al., 2003a; 2003c; 2004d; Ellis and Delaplane, 2008). In response, adult worker honey bees can detect SHB eggs/young larvae present in capped brood cells, uncap the cell, and remove the brood and/or SHB eggs/larvae (termed hygienic behaviour). A number of methods have been developed to facilitate studying SHB oviposition behaviour and the resulting honey bee hygienic responses to the behaviour.

\subsubsection{Promoting SHB oviposition behaviour in capped bee brood}

The idea of this method is that SHB adults are trapped and allowed to reproduce on a section of brood.

1. SHB used in the study can be laboratory-reared, fieldcollected, all males, all females, age-cohort specific, etc., per 
the needs of the experiment. They should be at least 1 week old to ensure that they have reached sexual maturity.

2. Remove a frame of capped brood ( $\sim 60-90 \%$ capped) from a colony.

The capped brood should not contain any uncapped larvae as these will crawl out of the cells and be macerated by the SHB in this procedure. Any uncapped larvae in the brood patch should be removed with forceps. It is best to use a section of brood that does not contain any honey stores. Furthermore, the selected brood should be $>6$ days from enclosing (determined by uncapping and examining select brood cells in the test area, see the section on obtaining workers and brood of know age in the BEEBOOK paper on miscellaneous methods, Human et al., 2013) so that no bees will emerge during the test period.

3. Prepare a sheet-metal, push-in cage $(10 \times 10 \times 2.5 \mathrm{~cm}$ cage, $\mathrm{L} \times \mathrm{W} \times \mathrm{H})$.

The face of the cage should be screen mesh to allow for ventilation. The screen mesh should be too small for SHB or bees to traverse.

4. Trap the required number of SHB in small vials.

5. Place the vials on ice 4-5 min.

6. Once anesthetized, dump the beetles onto the brood section. Trap the beetles on the section by pushing the cage onto the section and into the wax to the comb midrib.

7. Return the frame containing the beetles caged on a section of brood to the centre of the bee cluster in the colony from which the brood was removed.

8. Allow SHB to mate and the females to oviposit for 24 hours. Though the length of time for this can vary, the beetles may not oviposit in the brood cells sufficiently if allowed less time. In contrast, they decimate the brood section beyond use if allowed access longer than 24 hours. This is especially true if $>20$ adult SHB are added to the comb section.

9. After the oviposition period concludes, remove the combs from the colony

10. Collect the cages and beetles.

Note: It is important to know that some adult SHB may exit the cage during the oviposition period unless the cage is pushed firmly into the comb. Likewise, SHB already present in the colony at the time of the study can migrate into the cage. These situations usually only present a problem if one is trying to investigate the oviposition behaviour of an exact number of beetles.

\subsubsection{Identifying and marking brood cells in which SHB have oviposited}

1. Capped brood cells in which SHB have oviposited naturally or per the methods outlined in section 3.2.2.1. contain perforated cappings or side walls of the cell. The former is easy to note though the latter often requires a keen eye and the use of a flashlight.

2. Mark capped brood cells exposed to SHB and containing perforated cappings and/or side walls using a transparent sheet of plastic (acetate).

3. Cut the acetate to about the size of the face of the frame.

4. Mark the sheet with a permanent marker in one of the corners of the frame to identify its correct placement on the comb in subsequent observations.

5. Label the sheet according to frame and colony if several are used for replication.

6. Once the acetate is stable on the frame, use a permanent marker to place a small dot on top over all brood cells containing perforated cappings and/or side walls.

7. Once marked and labelled, remove the acetate sheet from the frame and store until needed.

\subsubsection{Determining honey bee hygienic responses to SHB eggs and young larvae.}

1. Following the methods outlined in sections 3.2.2.1. and 3.2.2.2., expose reproductive SHB adults to brood comb. They will breed, and the females might oviposit in capped brood cells.

2. Mark the cells (see section 3.2.2.2.).

3. Use a pin to put small holes in brood cell cappings as a positive control (Ellis et al., 2004d).

When pin-pricking, the holes should be made around the cap perimeter to avoid damaging the developing bee within the cell.

4. Mark capped brood cells with no perforations in the cappings and/or side walls as negative controls (Ellis and Delaplane, 2008).

5. Return the frame containing the perforated brood cells to the centre of the nest cluster.

Consequently, the brood section returned to the colony in step 3 will be investigated and attended to by worker bees. Honey bee workers that possess heightened hygienic responses can detect SHB eggs/ young larvae present in capped brood cells, uncap the cell, and remove the brood and/or SHB eggs/larvae (Ellis et al., 2003a, c; 2004d; Ellis and Delaplane, 2008).

6. Leave the frame containing the test section of brood in the nest for a predetermined amount of time.

Ellis et al. (2003c) left the brood in the colonies post exposure to SHB for 48 hours. However, worker bee hygienic response to the capped brood neared $100 \%$ in all test colonies so Ellis and Delaplane (2008) lessened the brood time in the colony to 24 hours in subsequent tests to look for colony differences in hygienic responses.

7. After the 24 hour period, remove the frame from the colony.

8. Replace the marked acetate (see section 3.2.2.2.) on the corresponding frame and align to the section of brood.

9. Consider hygienically removed the marked brood cells having 
perforated cappings/side walls the day before that no longer contained a developing bee.

10. Calculate the level of hygienic behaviour (or proportion of brood removed) as

\# marked brood cells containing no developing bee after 24 hours exposure to adult bees

total number of marked cells containing perforated side walls and/or cappings

The higher the proportion, the more hygienic the colony.

\subsubsection{Determining proportion of perforated capped brood cells containing SHB eggs (oviposition rate)}

1. Use the method outlined in section 3.2.2.3. to determine the oviposition rate of SHB females in capped brood.

2. A female SHB will not oviposit in all cells in which she perforates the capping and/or side wall. Consequently calculate the "oviposition rate" as:

\# marked capped brood cells containing SHB eggs

total number of marked capped brood cells containing perforated cappings and/or side walls

3. Open the cells marked according to section 3.2.2.3. with forceps.

4. Determine the number and presence of SHB eggs.

5. Remove the developing pupa/prepupa to facilitate egg quantification.

Potential additional uses:

The procedures outlined in sections 3.2.2.1. - 3.2.2.4. can be used to:

- investigate beetle density effects on oviposition (simply vary the number of SHB in the cages during the oviposition period),

- screen and possibly select for the level of hygienic expression of honey bees (within and between subspecies) toward SHB eggs and young larvae,

- determine time, environmental, bee subspecies, etc. impacts on SHB oviposition behaviour,

- determine colony strength impacts on hygienic behaviour (Ellis and Delaplane, 2008),

- and investigate other similar areas.

3.2.3. Determining the number and distribution of adult SHB inside a field colony and winter clusters and starting colonies without SHB

To estimate infestation loads of colonies and preferential SHB

locations, it is essential to quantify and locate the beetles adequately. Some experiments also require beetle-free colonies. Here we provide any overview on the respective methods.

\subsubsection{Visually screening the number of beetles in live} colonies and/or removing beetles to start beetle-free colonies These methods are modified from Ellis et al., 2002a; Ellis and Delaplane, 2006; Spiewok et al., 2007; 2008; Neumann and Hoffmann, 2008. The procedure is best accomplished with two people, one to work the colony and the second to collect the beetles.

1. Place a sheet of opaque plastic ( $2 \times 2 \mathrm{~m}$, preferably white or light in colour) or plywood in front of the colony in which you want to count the number of beetles.

2. Lightly smoke the colony.

3. Remove the lid from the colony.

4. Bounce the lid on the plywood. This dislodges all bees and beetles adhering to the lid.

5. A second individual (the beetle collector) combs through the bees by hand or with a small stick and collects all visible adult beetles with an aspirator. All bees on the plywood should be inspected since beetles can easily be concealed in clusters of bees.

6. Remove the outermost frame in the uppermost super.

7. Shake the bees from the frame onto the plywood.

8. The beetle collector repeats step 5 .

9. Once the bees have been shaken from the frame, turn the frame onto its face.

10. Bounce the frame against the plywood to dislodge adult beetles from the comb.

This step should be repeated 2-3 times for both sides of the frame.

11. The beetle collector repeats step 5 .

12. After all frames in a box have been examined, the individual working the colony bounces the empty box on the plywood to remove the remaining SHB. This step should be repeated for all supers, all frames, and the bottom board of the colony.

13. The bees accumulated on the plywood can be bounced off the board in front of the reassembled colony. The bees will return to the hive.

\section{Notes:}

A certain proportion of the adult SHB will remain undetected during such visual inspections (Neumann and Hoffmann, 2008). This procedure can be repeated 2-3 times in a 24 hour period in order to create beetle-free colonies for experiments.

\subsubsection{Counting the number and distribution of beetles in freshly-killed colonies}

A more accurate approach for counting SHB is to examine beetles in freshly-killed colonies (modified from Ellis et al., 2003a; Neumann and Hoffmann, 2008; Schäfer et al., 2011). One can, presumably, find $100 \%$ of the beetles inhabiting the nest if all the beetles and bees are dead. However, these methods are fatal to the colony and are useful only under certain circumstances. One of the following methods can be used to conduct absolute counts of SHB in colonies depending on what data are required and what facilities are available. 


\subsection{Killing with liquid nitrogen}

It is possible to kill whole colonies by dipping them into liquid nitrogen. The hives have to be manipulated to allow quick air displacement while keeping all bees and SHB inside. This can be achieved with a screened lid (mesh width, $1 \mathrm{~mm}$ ). As killing with liquid nitrogen is fast, the spatial distribution of the bees and the beetles inside or on the combs will remain stable.

1. Place an adequate container, filled with liquid nitrogen, next to the colony.

2. Install the screened lid.

3. Dip the colony into the liquid nitrogen.

4. Store the colonies in a cold room until they are carefully dissected.

Note: it is very important to follow the safety regulations for handling liquid nitrogen.

\subsection{Killing with petrol fuel}

Colonies can also be killed with petrol fuel. This method doesn't require hive manipulation, but one has to make sure, that no petrol fuel leaks out of the colony for environmental safety reasons.

1. Seal the complete hive with masking tape, except the lid.

2. Quickly open the top lid.

3. Pour $500 \mathrm{ml}$ standard petrol fuel into the colony.

4. Close the colony.

5. Store in a cold room until dissection.

Note: Petrol is poisonous for humans. Inspections should be done open air and gas masks or similar protection is highly recommended. Furthermore it is very important to be aware of the great flammability of petrol and its fumes!

\subsection{Freeze killing}

If large freezers are available, colonies can be killed by freezing them, but the placement of colonies into a cool room or freezer will change the distribution of SHB, because of the resulting clustering behaviour of the bees.

1. Close all colony entrances with tape, grass, or other similar material.

2. Place the colonies into a freezer room $\left(<-20^{\circ} \mathrm{C}\right)$ for 2 weeks to ensure that all the bees in the colonies are dead. It is important to note that honey bees are able to thermoregulate, so strong colonies with honey reserves (the fuel for thermoregulation) may die slowly. Wherever possible, colonies should be placed into very cold freezers and left for at least 2 weeks. Colonies kept at temperatures $>-20^{\circ} \mathrm{C}$ may die too slowly.

Regardless of which way of killing, the SHB in the stored colonies are counted as follows:

1. Thaw the colonies at RT for 24 hours prior to inspection for beetles.
2. Once thawed, remove the lid to the colony.

3. Carefully inspect for beetles. Bees should be removed to facilitate beetle visualization and cracks/crevices examined carefully.

4. Remove all frames from the colony

5. Inspect each frame for beetles.

This includes removing bees from the combs, tapping the combs on their sides to dislodge beetles hiding in the wax cells and uncapping of sealed honey combs to detect mining larvae (Neumann and Hoffmann, 2008). It is important to note that bees cluster in cold temperatures, with many bees clustering head first into empty cells. Beetles often can be found at the bottom of cells that bees are in (Ellis et al., 2003a) so all clustering bees should be removed from all cells (this can be done using forceps) in order to find every beetle present in the nest.

6. Inspect all supers and the bottom board for hiding beetles.

\subsubsection{Counting the number of beetles and defining their spatial distribution in winter clusters killed by dipping in liquid nitrogen}

This method is modified from Schäfer et al. (2011). It is an accurate method for counting the number and determining the spatial distribution of adult SHB inside honey bee winter clusters. One can, presumably, find $100 \%$ of the beetles inhabiting the colony. However, the method is fatal to the colony and is useful only under certain circumstances. Furthermore, it requires manipulation of the hives and the availability of liquid nitrogen and a cool room that can accommodate the clustering colonies.

1. Place the colonies in hives without entrances and with screened bottom and lid (mesh width, $1 \mathrm{~mm}$ ).

2. Transfer the colonies into a cold room at $-5^{\circ} \mathrm{C}$ and constant darkness, to allow the formation of the clusters.

3. Kill the colonies by dipping the whole hives into liquid nitrogen (see section 3.2.3.2.1.), immediately after taking them out of the cool room.

This will fix the spatial distribution of adult $A$. tumida inside the clusters and keep the structure of the cluster.

4. Leave the colonies inside the liquid nitrogen long enough to kill all the bees and SHB (1 min. for a cluster of 4,000 bees).

5. Store the colonies in a cold room until they are carefully dissected.

6. Record the position of the cluster (e.g. by taking pictures) and of each SHB (all bees inside cells have to be removed to investigate the cell bottoms).

The positions of SHB can be recorded as follows: core (= central area of the cluster), periphery (= inside cluster, except core area) and outside clusters or elsewhere inside the colony.

Note: it is very important to follow the safety regulations for handling liquid nitrogen. 


\subsubsection{Collecting SHB eggs}

This method has been designed by Ellis and Delaplane (2007)

1. Lay a microscope slide on a flat surface.

2. Place $1 / 2$ of a cover slip on both ends of the slide.

3. Place another microscope slide on top of the cover slip halves. In effect, you are separating two microscope slides with a cover slip.

4. Tape both ends of the slides so that they will remain together.

5. Place the slides in a petri dish that contains a small amount $(\sim 5 \mathrm{~g})$ of SHB food (see section 3.1.1.1. for food recipe).

6. Add mated females or adult beetles (see section 3.1.3.) to the petri dish and replace the petri dish top.

7. Secure the top and bottom of the petri dish to one another with a rubber band.

SHB females will oviposit in the space between the two slides created by the cover slip (see Fig. 12).

8. Handle SHB eggs with a small paint brush.

This procedure can be modified by using a small piece of wax paper $(\sim 10 \mathrm{~cm} \times 10 \mathrm{~cm})$ that has been folded back and forth 10 times (making $\sim 1 \mathrm{~cm}$ folds). The folds should be tight and the ends of the paper should be paper clipped to keep it from unfolding. The SHB females will oviposit between the folds in the paper.

\subsubsection{Introducing adult SHB into colonies}

Ellis et al. (2003b) investigated the impacts of adult SHB on nests and flight activity of Cape and European subspecies of honey bees. They did this by adding SHB to nucleus colonies nightly for 15 nights to simulate a large-scale, chronic invasion of SHB into colonies. They developed the method outlined below for introducing adult SHB into colonies daily.

1. Rear adult SHB according to the methods outlined in section 3.1.3.

2. Prepare/equalize colonies prior to the experiments according to the methods outlined in the $B E E B O O K$ paper on estimating colony strength (Delaplane et al., 2013).

3. Collect adult SHB from the rearing program with an aspirator (see Fig. 6).

4. Place the exact number and sex (if needed see Fig. 9) of adult SHB intended for each colony into small vials before their release into the colonies. Adult SHB are much easier to release from a vial into a colony than by other methods.

5. Colonies can be artificially-infested with SHB on any time schedule (daily, weekly, etc.) provided the introductions are done during evening hours. SHB adults preferentially invade colonies during evening hours (Neumann et al., 2012) so adults should be introduced during regionally-appropriate hours, between 1-2 hours before sunset and 1-2 hours after sunset. Ellis et al. (2003b) introduced SHB between 17:00 - 21:00 h.

5. To introduce SHB into the colony, lightly tap the vial containing the beetles to cause the beetles to fall to the bottom of the vial.
SHB are quick crawlers and can easily escape the vial once the lid is removed if they are not tapped to the bottom of the vial first.

6. Open the lid to the colony just enough to allow room to add the beetles.

7. Add the adults to the uppermost super of the hive and close to the nest periphery to avoid overreaction by the host bees ("beetle shock": bees being exposed to SHB abnormally and immediately removing the beetles from the hive). If the beetles are dumped into the centre of the bee cluster, the bees will attack the beetles immediately and many beetles may exit the colony within minutes of introduction. Beetles should not be anesthetized prior to introduction into the nest because anesthetized beetles are easily removed from colonies by adult bees.

8. Replace the lid to the colony immediately after beetle introduction.

Modifications, additional uses, research on future improvements:

- The same method can be used to add adult SHB to full-size or nucleus colonies and to observation hives. Modifications can be made to the observation hive to accommodate SHB introduction since observation hive lids often cannot be removed (depending on hive design) (Fig. 14).

- Ellis et al. (2003b) added $100 \mathrm{SHB} /$ night for 15 nights (totalling 1,500 SHB). Delaplane et al. (2010) added from 75 $-1,200 \mathrm{SHB} /$ introduction every two months for a beetle threshold study. Consequently, the method is useful to simulate chronic, small scale beetle invasions or large, acute beetle invasions into the bee nest.

- For possible future improvement, one should investigate how SHB can be "control-released" into the nest over a longer period of time. The method outlined above involves the sudden addition of SHB adults to the nest, heightening the likelihood of "beetle shock". Controlled introductions should be a point of future investigation.

- This procedure can be used to investigate SHB impacts on colony absconding behaviour, honey and pollen stores, amount of bees/brood in the nest, average colony flight activity, colony weight gain, SHB reproduction, SHB migration between colonies, etc. The beetles can be laboratory-reared, field-collected, all males, all females, age-cohort specific, etc. according to the needs of the experiment.

- Neumann and Härtel (2004) investigated the removal of SHB larvae by honey bee colonies. They introduced larvae using petri-dishes. Since SHB larvae are neither quick crawlers nor able to show the turtle defence posture of adult SHB (Neumann et al., 2001c), worker bees quickly remove them (Neumann and Härtel, 2004). 

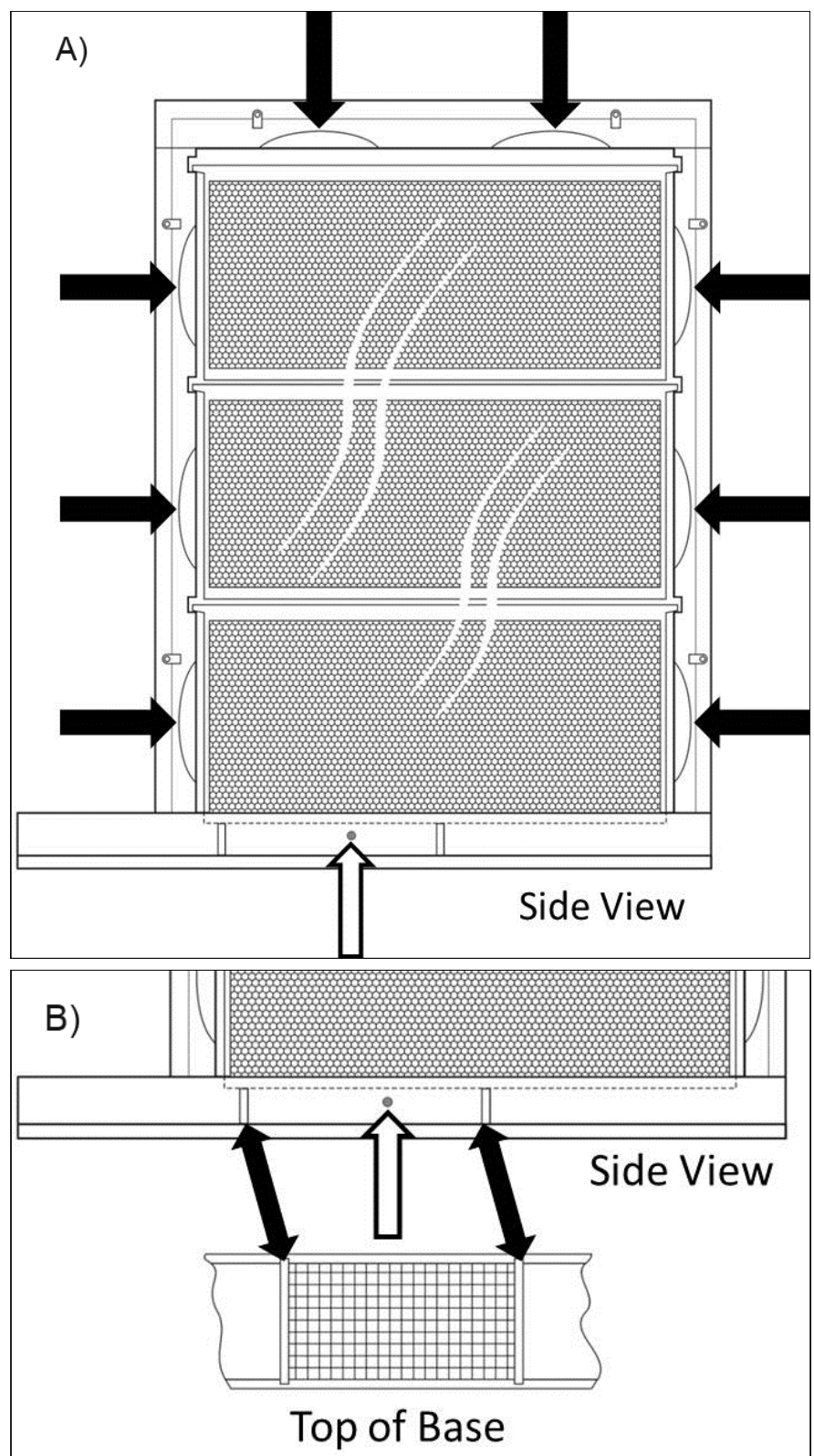

Fig. 14. Diagram of the modified observation hive used by Atkinson and Ellis $(2011 a, b)$. A. shows a side view of the observation hive. The white arrow indicates the location where beetles are introduced into the observation hive, while the black arrows indicate the location of the eight grooves (confinement sites) located on the periphery of the observation hive. The confinement sites are present on both sides, totalling 16 sites. Invading beetles are more likely to be confined in these sites (facilitating their observation) than in other locations in the nest. $\boldsymbol{B}$. shows the bottom board of the observation hive (top picture) and a top view of the gridded base (test arena) of the observation hive. The white arrow indicates the location where beetles or control beads can be introduced into the test arena. The black arrows indicate the location of the acrylic glass doors that, when slid in place, capture guard bees in the test arena.
SHB have now well established populations in North America and Australia (Neumann and Ellis, 2008), and are likely to spread into more areas (Asia, South America, Europe) with potentially devastating effects on local managed honey bees and possibly other bees under suitable climatic conditions. This calls for concerted efforts of the community to better control this invasive species. However, despite this $B E E B O O K$ paper there are still significant gaps in $\mathrm{SHB}$ methodology, thereby limiting its further study and control. This calls for more research in this rather small field. Development of alternative treatments with natural enemies or an optimized trapping of adult/ larval SHB in the field might constitute promising future avenues. On the other hand, this beetle has a truly fascinating biology and there is considerable potential to shed light on numerous fundamental questions in ecology and evolution. We therefore hope that this set of standard methods will attract more researchers to join the SHB research field, thereby stimulating exciting future research on this species.

\section{Acknowledgements}

Appreciation is addressed to Geoff Williams and an anonymous referee for constructive comments on an earlier draft of the manuscript and to Sebastian Spiewok for sharing his unpublished data. The COLOSS (Prevention of honey bee COlony LOSSes) network aims to explain and prevent massive honey bee colony losses. It was funded through the COST Action FA0803. COST (European Cooperation in Science and Technology) is a unique means for European researchers to jointly develop their own ideas and new initiatives across all scientific disciplines through trans-European networking of nationally funded research activities. Based on a pan-European intergovernmental framework for cooperation in science and technology, COST has contributed since its creation more than 40 years ago to closing the gap between science, policy makers and society throughout Europe and beyond. COST is supported by the EU Seventh Framework Programme for research, technological development and demonstration activities (Official Journal L 412, 30 December 2006). The European Science Foundation as implementing agent of COST provides the COST Office through an EC Grant Agreement. The Council of the European Union provides the COST Secretariat. The COLOSS network is now supported by the Ricola Foundation - Nature \& Culture. 


\section{References}

ANDERSON, D L; ROBERTS, J M K (2013) Standard methods for Tropilaelaps mites research. In V Dietemann; J D Ellis; P Neumann (Eds) The COLOSS BEEBOOK, Volume II: standard methods for Apis mellifera pest and pathogen research. Journal of Apicultural Research 52(4): http://dx.doi.org/10.3896/IBRA.1.52.4.21 ARBOGAST, R T; TORTO, B; VAN ENGELSDORP, D; TEAL, P E A

(2007) An effective trap and bait combination for monitoring the small hive beetle, Aethina tumida (Coleoptera: Nitidulidae). Florida Entomologist 90(2): 404-406.

ARBOGAST, R T; TORTO, B; WILLMS, S; FOMBONG, A T; DUEHL, A; TEAL, P E A (2012) Estimating reproductive success of Aethina tumida (Coleoptera: Nitidulidae) in honey bee colonies by trapping emigrating larvae. Environmental Entomology 41(1): 152-158. http://dx.doi.org/10.1603/EN11186

ATKINSON, E; ELLIS, J D (2011a) Adaptive behaviour of honey bees (Apis mellifera) toward beetle invaders exhibiting various levels of colony integration. Physiological Entomology 36: 282-289. http://dx.doi.org/10.1111/j.1365-3032.2010.00774.x

ATKINSON, E; ELLIS, J D (2011b) Honey bee, Apis mellifera L., confinement behaviour toward beetle invaders. Insectes Sociaux 58: 495-503. http://dx.doi.org/10.1007/s00040-011-0169-7

BENDA, N D; BOUCIAS, D; TORTO, B; TEAL P (2008) Detection and characterization of Kodamaea ohmeri associated with small hive beetle Aethina tumida infesting honey bee hives. Journal of Apicultural Research 47(3): 194-201.

http://dx.doi.org/10.3827/IBRA.1.47.3.07

BUCHHOLZ, S; SCHÄFER, M O; SPIEWOK, S, PETTIS J S, DUNCAN M, RITTER W, SPOONER-HART R, NEUMANN P (2008) Alternative food sources of Aethina tumida (Coleoptera: Nitidulidae). Journal of Apicultural Research 47(3): 201-208.

http://dx.doi.org/10.3827/IBRA.1.47.3.08

DE GRAAF, D C; ALIPPI, A M; ANTÚNEZ, K; ARONSTEIN, K A; BUDGE, G; DE KOKER, D; DE SMET, L; DINGMAN, D W; EVANS, J D; FOSTER, L J; FÜNFHAUS, A; GARCIA-GONZALEZ, E; GREGORC, A; HUMAN, H; MURRAY, K D; NGUYEN, B K; POPPINGA, L; SPIVAK, M; VANENGELSDORP, D; WILKINS, S; GENERSCH, E (2013) Standard methods for American foulbrood research. In V Dietemann; $J D$ Ellis; P Neumann (Eds) The COLOSS BEEBOOK, Volume II: standard methods for Apis mellifera pest and pathogen research Journal of Apicultural Research 52(1):

http://dx.doi.org/10.3896/IBRA.1.52.1.11

DE GUZMAN, L I; PRUDENTE, J A; RINDERER, T E; FRAKE, A M; TUBBS, $\mathrm{H}$ (2009) Population of small hive beetles (Aethina tumida Murray) in two apiaries having different soil textures in Mississippi. Science of Bee Culture, 1: 4-8.

DE GUZMAN, L I; FRAKE, A M; RINDERER, T E; ARBOGAST R T

(2011) Effect of height and colour on the efficiency of pole traps for Aethina tumida (Coleoptera: Nitidulidae). Journal of Economic Entomology 104(1): 26-31. http://dx.doi.org/10.1603/EC10300
DE GUZMAN, L I; FRAKE, A M; RINDERER, T E (2012) Marking small hive beetles with thoracic notching: effects on longevity, flight ability and fecundity. Apidologie 43: 425-431. http://dx.doi.org/10.1007/s13592-011-0107-8

DELAPLANE, K S; VAN DER STEEN, J; GUZMAN, E (2013) Standard methods for estimating strength parameters of Apis mellifera colonies. In V Dietemann; J D Ellis; P Neumann (Eds) The COLOSS BEEBOOK, Volume I: standard methods for Apis mellifera research. Journal of Apicultural Research 52(1): http://dx.doi.org/10.3896/IBRA.1.52.1.03

DE MIRANDA, J R; BAILEY, L; BALL, B V; BLANCHARD, P; BUDGE, G; CHEJANOVSKY, N; CHEN, Y-P; GAUTHIER, L; GENERSCH, E; DE GRAAF, D; RIBIÈRE, M; RYABOV, E; DE SMET, L VAN DER STEEN, J J M (2013) Standard methods for virus research in Apis mellifera. In V Dietemann; J D Ellis; P Neumann (Eds) The COLOSS BEEBOOK, Volume II: standard methods for Apis mellifera pest and pathogen research. Journal of Apicultural Research 52(4): http://dx.doi.org/10.3896/IBRA.1.52.4.22

DELAPLANE, K S; ELLIS, J D; HOOD, W M (2010) A test for interactions between Varroa destructor (Acari: Varroidae) and Aethina tumida (Coleoptera: Nitidulidae) in colonies of honey bees (Hymenoptera: Apidae). Annals of the Entomological Society of America 103(5): 711-715. http://dx.doi.org/10.1603/AN09169

DIETEMANN, V; NAZZI, F; MARTIN, S J; ANDERSON, D; LOCKE, B; DELAPLANE, K S; WAUQUIEZ, Q; TANNAHILL, C; FREY, E; ZIEGELMANN, B; ROSENKRANZ, P; ELLIS, J D (2013) Standard methods for varroa research. In $V$ Dietemann; J D Ellis; P Neumann (Eds) The COLOSS BEEBOOK, Volume II: standard methods for Apis mellifera pest and pathogen research. Journal of Apicultural Research 52(1):

http://dx.doi.org/10.3896/IBRA.1.52.1.09

ELLIS, J D (2005) Reviewing the confinement of small hive beetles (Aethina tumida) by western honey bees (Apis mellifera). Bee World 86(3): 56-62.

ELLIS, J D; DELAPLANE, K S (2006) The effects of habitat type, ApilifeVAR $^{\mathrm{TM}}$, and screened bottom boards on small hive beetle (Aethina tumida) entry into honey bee (Apis mellifera) colonies. American Bee Journal 146(5): 537-539.

ELLIS, J D; DELAPLANE, K S (2007) The effects of three acaricides on the developmental biology of small hive beetles (Aethina tumida). Journal of Apicultural Research 46(4): 256-259. http://dx.doi.org/10.3896/IBRA.1.46.4.08

ELLIS, J D; DELAPLANE, K S (2008) Small hive beetle (Aethina tumida) oviposition behaviour in sealed brood cells with notes on the removal of the cell contents by European honey bees (Apis mellifera). Journal of Apicultural Research 47(3): 210-215. http://dx.doi.org/10.3896/IBRA.1.47.3.09

ELLIS, J D; DELAPLANE, K S; HEPBURN, H R; ELZEN, P J (2002a) Controlling small hive beetles (Aethina tumida Murray) in honey bee (Apis mellifera) colonies using a modified hive entrance. American Bee Journal 142(4): 288-290. 
ELLIS J D; DELAPLANE K S, HOOD W M (2002b) Small hive beetle (Aethina tumida Murray) weight, gross biometry, and sex proportion at three locations in the southeastern United States. American Bee Journal 142(7):520-522.

ELLIS, J D; HEPBURN, H R (2006) An ecological digest of the small hive beetle (Aethina tumida), a symbiont in honey bee colonies (Apis mellifera). Insectes Sociaux 53: 8-19. http://dx.doi.org/10.1007/s00040-005-0851-8

ELLIS, J D; MUNN, P A (2005) The worldwide health status of honey bees. Bee World 86(4): 88-101.

ELLIS, J D; HEPBURN, H R; DELAPLANE, K S; ELZEN, P J (2003a) A scientific note on small hive beetle (Aethina tumida) oviposition and behaviour during European (Apis mellifera) honey bee clustering and absconding events. Journal of Apicultural Research 42(3): 47-48.

ELLIS, J D; HEPBURN, H R; DELAPLANE, K S; NEUMANN, P; ELZEN, P J (2003b) The effects of adult small hive beetles, Aethina tumida (Coleoptera: Nitidulidae), on nests and flight activity of Cape and European honey bees (Apis mellifera). Apidologie 34: 399-408. http://dx.doi.org/10.1051/apido:2003038

ELLIS, J D; HEPBURN, H R; ELLIS, A M; ELZEN, P J (2003c) Prison construction and guarding behaviour by European honey bees is dependent on inmate small hive beetle density.

Naturwissenschaften 90: 382-384.

http://dx.doi.org/10.1007/s00114-003-0447-y

ELLIS, J D; HEPBURN, H R; ELLIS, A M; ELZEN, P J (2003d) Social encapsulation of the small hive beetle (Aethina tumida Murray) by European honey bees (Apis mellifera L.). Insectes Sociaux 50: 286 -291. http://dx.doi.org/10.1007/s00040-003-0671-7

ELLIS, J D; HOLLAND, A J; HEPBURN, H R; NEUMANN, P; ELZEN, P J (2003e) Cape (Apis mellifera capensis) and European (Apis mellifera) honey bee guard age and duration of guarding small hive beetles (Aethina tumida). Journal of Apicultural Research 42 (3): $32-34$

ELLIS, J D; HEPBURN, H R; ELZEN, P J (2004a) Confinement behaviour of cape honey bees (Apis mellifera capensis Esch.) in relation to population densities of small hive beetles (Aethina tumida Murray). Journal of Insect Behaviour 17(6): 835-842. http://dx.doi.org/10.1023/B:JOIR.0000048992.26016.7f

ELLIS, J D; HEPBURN, H R; ELZEN P J (2004b) Confinement of small hive beetles (Aethina tumida) by Cape honey bees (Apis mellifera capensis). Apidologie 35(4): 389-396.

http://dx.doi.org/10.1051/apido:2004030

ELLIS, J D; HEPBURN, H R, LUCKMANN, B; ELZEN, P J (2004c) The effects of soil type, moisture, and density on pupation success of Aethina tumida (Coleoptera: Nitidulidae). Environmental Entomology 33(4): 794-798. http://dx.doi.org/10.1603/0046-225X-33.4.794
ELLIS, J D; DELAPLANE, K S; HOOD, W M (2002a) Small hive beetle (Aethina tumida Murray) weight, gross biometry, and sex proportion at three locations in the south-eastern United States. American Bee Journal 142: 520-522.

ELLIS, J D; NEUMANN, P, HEPBURN, H R; ELZEN, P J (2002b) Longevity and reproductive success of Aethina tumida (Coleoptera: Nitidulidae) fed different natural diets. Journal of Economic Entomology 95(5): 902-907.

http://dx.doi.org/10.1603/0022-0493-95.5.902

ELLIS, J D; PIRK, C W W; HEPBURN, H R; KASTBERGER, G; ELZEN, P J (2002c) Small hive beetles survive in honey bee prisons by behavioural mimicry. Naturwissenschaften 89: 326-328. http://dx.doi.org/10.1007/s00114-002-0326-y

ELLIS, J D; RICHARDS, C S; HEPBURN, H R; ELZEN, P J (2003f) Oviposition by small hive beetles elicits hygienic responses from Cape honey bees. Naturwissenschaften 90(11): 532-535. http://dx.doi.org/10.1007/s00114-003-0476-6

ELLIS, J D; RICHARDS, C S; HEPBURN, H R; ELZEN, P J (2004d) Hygienic behaviour of Cape and European Apis mellifera (Hymenoptera: Apidae) toward Aethina tumida (Coleoptera: Nitidulidae) eggs oviposited in sealed bee brood. Annals of the Entomological Society of America 97(4): 860-864. http://dx.doi.org/10.1603/0013-8746(2004)097[0860:HBOCAE] 2.0.CO;2

ELLIS, J D; RONG, I H; HILL, M P; HEPBURN, H R; ELZEN, P J (2004e) The susceptibility of small hive beetle (Aethina tumida Murray) pupae to fungal pathogens. American Bee Journal 144 (6): 486-488.

ELLIS, ] D; SPIEWOK, S; DELAPLANE, K S; BUCHHOLZ, S; NEUMANN, P; TEDDERS, L (2010) Susceptibility of Aethina tumida (Coleoptera: Nitidulidae) larvae and pupae to entomopathogenic nematodes. Journal of Economic Entomology 103(1): 1-9. http://dx.doi.org/10.1603/EC08384

ELZEN, P J; BAXTER, J R; WESTERVELT, D; RANDALL, C; DELAPLANE, K S; CUTTS, L; WILSON, W T (1999) Field control and biology studies of a new pest species, Aethina tumida Murray (Coleoptera: Nitidulidae), attacking European honey bees in the Western Hemisphere. Apidologie 30: 361-366. http://dx.doi.org/10.1051/apido:19990501

ELZEN, P J; BAXTER, J R; NEUMANN, P; SOLBRIG, A J; PIRK, C W W; HEPBURN, H R; WESTERVELT, D; RANDALL, C (2001) Behaviour of African and European subspecies of Apis mellifera toward the small hive beetle, Aethina tumida. Journal of Apicultural Research 40: $40-41$.

EYER, M ; CHEN, Y P ; SCHÄFER, M O; PETTIS, J; NEUMANN, P (2009a) Small hive beetle, Aethina tumida, as a potential biological vector of honey bee viruses. Apidologie 40: 419-428. http://dx.doi.org/10.1051/apido:2008051 
EYER, M ; CHEN, Y P ; SCHÄFER, M O; PETTIS, J; NEUMANN, P

(2009b) Honey bee sacbrood virus infects adult small hive beetles, Aethina tumida (Coleoptera: Nitidulidae). Journal of Apicultural Research 48(4): 296-297.

http://dx.doi.org/10.3896/IBRA.1.48.4.11

EVANS, J D; PETTIS, J S; SHIMANUKI, H (2000). Mitochondrial DNA relationships in an emergent pest of honey bees: Aethina tumida (Coleoptera: Nitidulidae) from the United States and Africa. Annals of the Entomological Society of America 93: 415-420. http://dx.doi.org/10.1603/0013-8746(2000)093[0415:MDRIAE] 2.0.CO;2

EVANS, J D; PETTIS, J S; HOOD, H; SHIMANUKI, H (2003). Tracking an invasive honey bee pest: Mitochondrial DNA variation in North American small hive beetles. Apidologie. 34: 103-109. http://dx.doi.org/10.1051/apido:2003004

EVANS, J D; SPIEWOK, S; TEIXEIRA, E W; Neumann, P (2008) Microsatellite loci for the small hive beetle, Aethina tumida, a nest parasite of honey bees. Molecular Ecology Resources 8: 698-700. http://dx.doi.org/10.1111/j.1471-8286.2007.02052.x

EVANS, J D; SCHWARZ, R S; CHEN, Y P; BUDGE, G; CORNMAN, R S; DE LA RUA, P; DE MIRANDA, J R; FORET, S; FOSTER, L; GAUTHIER, L; GENERSCH, E; GISDER, S; JAROSCH, A; KUCHARSKI, R; LOPEZ, D; LUN, C M; MORITZ, R F A; MALESZKA, R; MUÑOZ, I; PINTO, M A (2013) Standard methodologies for molecular research in Apis mellifera. In V Dietemann; J D Ellis; P Neumann (Eds) The COLOSS BEEBOOK, Volume I: standard methods for Apis mellifera research. Journal of Apicultural Research 52(4): http://dx.doi.org/10.3896/IBRA.1.52.4.11

FALUSH, D; STEPHENS, M; PRITCHARD, J K (2007) Inference of population structure using multilocus genotype data: dominant markers and null alleles. Molecular Ecology Notes 7 (4): 574-578. http://dx.doi.org/10.1111/j.1471-8286.2007.01758.x

FREUDE, H; HARDE, K W; LOHSE, G A (1967) Die Käfer Mitteleuropas, Goecke und Evers, Krefeld, 72 pp.

GRECO, M K; HOFFMANN, D; DOLLIN, A; DUNCAN, M; SPOONERHART, R; NEUMANN, P (2010) The alternative Pharaoh approach: stingless bees mummify beetle parasites alive.

Naturwissenschaften 97: 319-323.

http://dx.doi.org/10.1007/s00114-009-0631-9

HALCROFT, M; SPOONER-HART, R; NEUMANN, P (2011) Behavioral defense strategies of the stingless bee, Austroplebeia australis, against the small hive beetle, Aethina tumida. Insectes Sociaux 58: 245-253. http://dx.doi.org/10.1007/s00040-010-0142-x HEPBURN, H R; RADLOFF, S E (1998) Honey bees of Africa. Springer Verlag; Berlin, Germany.

HOFFMANN, D; PETTIS, J S; NEUMANN, P (2008) Potential host shift of the small hive beetle (Aethina tumida) to bumble bee colonies (Bombus impatiens). Insectes Sociaux 55: 153-162 http://dx.doi.org/10.1007/s00040-008-0982-9
HOOD, W M (2004) The small hive beetle, Aethina tumida: a review. Bee World 85: 51-59.

HUMAN, H; BRODSCHNEIDER, R; DIETEMANN, V; DIVELY, G; ELLIS, J; FORSGREN, E; FRIES, I; HATJINA, F; HU, F-L; JAFFÉ, R; JENSEN, A B; KÖHLER, A; MAGYAR, J; ÖZIKRIM, A; PIRK, C W W; ROSE, R; STRAUSS, U; TANNER, G; TARPY, D R; VAN DER STEEN, J J M; VAUDO, A; VEJSNÆS, F; WILDE, J; WILLIAMS, G R; ZHENG, H-Q (2013) Miscellaneous standard methods for Apis mellifera research. In V Dietemann; J D Ellis; P Neumann (Eds) The COLOSS BEEBOOK, Volume I: standard methods for Apis mellifera research. Journal of Apicultural Research 52(4):

http://dx.doi.org/10.3896/IBRA.1.52.4.10

JENSEN, A B; ARONSTEIN, K; FLORES, J M; VOJVODIC, S; PALACIO, M A; SPIVAK, M (2013) Standard methods for fungal brood disease research. In V Dietemann; J D Ellis, P Neumann (Eds) The COLOSS BEEBOOK: Volume II: Standard methods for Apis mellifera pest and pathogen research. Journal of Apicultural Research 52(1): http://dx.doi.org/10.3896/IBRA.1.52.1.13

KÖHLER, A; NICOLSON, S W; PIRK, C W W (2013) A new design for honey bee hoarding cages for laboratory experiments. Journal of Apicultural Research 52(2): 12-14.

http://dx.doi.org/10.3896/IBRA.1.52.2.03

KOLMES, S A (1985) An information-theory analysis of task specialization among worker honey bees performing hive duties. Animal Behaviour 33: 181-187.

LOUNSBERRY, Z; SPIEWOK, S; PERNAL, S F; SONSTEGARD, T S; HOOD, W M; PETTIS, J S; NEUMANN, P; EVANS, J D (2010) Worldwide diaspora of the small hive beetle, Aethina tumida, a nest parasite of honey bees, Apis mellifera. Annals of the Entomological Society of America 103: 671-677. http://dx.doi.org/10.1603/AN10027

LUNDIE, A E (1940) The small hive beetle Aethina tumida. Science Bulletin 220: Department of Agriculture and Forestry, Government Printer; Pretoria, South Africa. $30 \mathrm{pp}$.

MEIXNER, M D; PINTO, M A; BOUGA, M; KRYGER, P; IVANOVA, E; FUCHS, S (2013) Standard methods for characterising subspecies and ecotypes of Apis mellifera. In V Dietemann; J D Ellis; $P$ Neumann (Eds) The COLOSS BEEBOOK, Volume I: standard methods for Apis mellifera research. Journal of Apicultural Research 52(4): http://dx.doi.org/10.3896/IBRA.1.52.4.05 MORITZ, R F A; CREWE, R M; HEPBURN, H R (2001) Attraction and repellence of workers by the honey bee queen (Apis mellifera L.). Ethology 107: 465-477. http://dx.doi.org/10.1046/j.1439-0310.2001.00681.x

MURILHAS, A M (2005) Aethina tumida arrives in Portugal. Will it be eradicated? EurBee Newsletter 2: 7-9.

MURRAY, A (1867) List of Coleoptera received from Old Calabar, on the west coast of Africa. The Annals and Magazine of Natural History 19: 167. 
MUERRLE, T M; NEUMANN, P (2004) Mass production of small hive beetles (Aethina tumida Murray, Coleoptera: Nitidulidae). Journal of Apicultural Research 43(3): 144-145.

MUERRLE, T M; NEUMANN, P; DAMES, J F; HEPBURN, H R; HILL, M P (2006) Susceptibility of adult small hive beetle to entomopathogenic fungi. Journal of Economic Entomology 99: 1-6. http://dx.doi.org/10.1603/0022-0493(2006)099[0001:SOAATC] 2.0.CO;2

NEUMANN, P; HÄRTEL, S (2004) Removal of small hive beetle (Aethina tumida Murray) eggs and larvae by African honey bee colonies (Apis mellifera scutellata Lepeletier). Apidologie 35: 3136. http://dx.doi.org/10.1051/apido:2003058

NEUMANN, P; ELLIS, J D (2008) The small hive beetle (Aethina tumida Murray, Coleoptera: Nitidulidae): distribution, biology and control of an invasive species. Journal of Apicultural Research 47 (3): 180-183. http://dx.doi.org/10.3896/IBRA.1.47.3.01

NEUMANN, P; ELZEN, P J (2004) The biology of the small hive beetle (Aethina tumida, Coleoptera: Nitidulidae): Gaps in our knowledge of an invasive species. Apidologie 35: 229-247. http://dx.doi.org/10.1051/apido:2004010

NEUMANN, P; RITTER, W (2004) A scientific note on the association of Cychramus luteus (Coleoptera: Nitidulidae) with honey bee (Apis mellifera) colonies. Apidologie 35: 665-666. http://dx.doi.org/10.1051/apido:2004051

NEUMANN, P; HOFFMANN, D (2008) Small hive beetle diagnosis and control in naturally infested honey bee colonies using bottom board traps and CheckMite+ strips. Journal of Pest Science 81: 43 -48. http://dx.doi.org/10.1007/s10340-007-0183-8

NEUMANN, P; PIRK, C W W; HEPBURN, H R; EELZEN, P J; BAXTER, J R (2001a) Laboratory rearing of small hive beetle, Aethina tumida (Coleoptera: Nitidulidae). Journal of Apicultural Research 40: 111-112. NEUMANN, P; PIRK, C W W; HEPBURN, H R; RADLOFF, S E (2001b)

A scientific note on the natural merger of two honey bee colonies (Apis mellifera capensis). Apidologie 32: 113-114.

http://dx.doi.org/10.1051/apido:2001116

NEUMANN, P; PIRK, C W W; HEPBURN, H R; SOLBRIG, A J;

RATNIEKS, F L W; ELZEN, P J; BAXTER, J R (2001c) Social encapsulation of beetle parasites by Cape honey bee colonies (Apis mellifera capensis Esch.). Naturwissenschaften 88: 214-216. http://dx.doi.org/10.1007/s001140100224

NEUMANN, P; RADLOFF, S E; PIRK, C W W; HEPBURN, H R (2003)

The behaviour of drifted Cape honey bee workers (Apis mellifera capensis): predisposition for social parasitism? Apidologie 34: 585590. http://dx.doi.org/10.1051/apido:2003048

NEUMANN, P; HOFFMANN, D; DUNCAN, M; SPOONER-HART, R; PETTIS, J S (2012) Long-range dispersal of small hive beetles. Journal of Apicultural Research 51(2): 214-215. http://dx.doi.org/10.3896/IBRA.1.51.2.11
PEAKALL, R; SMOUSE, P E (2006) Genalex 6: genetic analysis in Excel. Population genetic software for teaching and research. Molecular Ecology Notes 6 (1): 288-295.

http://dx.doi.org/10.1111/j.1471-8286.2005.01155.x

PENG, C; WILLIAMS, R N (1990a) Multiple-species rearing diet for sap beetles (Coleoptera: Nitidulidae). Annals of the Entomological Society of America 83(6): 1155-1157.

PENG, C; WILLIAMS, R N (1990b) Pre-oviposition period, egg production and mortality of six species of hibernating sap beetles (Coleoptera: Nitidulidae). Journal of Entomological Science 25(3): 453-457.

PETTIS, J S; SHIMANUKI, H (2000) Observations on the small hive beetle, Aethina tumida, Murray, in the United States, American Bee Journal 140, 152-155.

PIRK, C W W (2002) Reproductive conflicts in honey bee colonies. PhD thesis, Department of Zoology \& Entomology, Rhodes University, South Africa.

PIRK, C W W; NEUMANN, P (2013) Small hive beetles are facultative predators of adult honey bees. Journal of Insect Behaviour 26: http://dx.doi.org/10.1007/s10905-013-9392-6

PIRK, C W W; DE MIRANDA, J R; FRIES, I; KRAMER, M; PAXTON, R; MURRAY, T; NAZZI, F; SHUTLER, D; VAN DER STEEN, J J M; VAN DOOREMALEN, C (2013) Statistical guidelines for Apis mellifera research. In V Dietemann; J D Ellis; P Neumann (Eds) The COLOSS BEEBOOK, Volume I: standard methods for Apis mellifera research. Journal of Apicultural Research 52(4): http://dx.doi.org/10.3896/IBRA.1.52.4.13

RÖSCH, G A (1925) Untersuchungen über die Arbeitsteilung im Bienenstaat. 1. Teil: Die Tätigkeiten im normalen Bienenstaate und ihre Beziehungen zum Alter der Arbeitsbienen. Zeitschrift für vergleichende Physiologie 2: 571-631.

SCHÄFER, M O; PETTIS, J S; RITTER, W; NEUMANN, P (2008) A scientific note on quantitative diagnosis of small hive beetles, Aethina tumida, in the field. Apidologie 39: 564-565. http://dx.doi.org/10.1051/apido:2008038

SCHÄFER, M O; PETTIS, J S; RITTER, W; NEUMANN, P (2010a) Simple small hive beetle diagnosis. American Bee Journal 150: 371-372.

SCHÄFER, M O; RITTER, W; PETTIS, J S; NEUMANN, P (2010b) Small hive beetles, Aethina tumida, are vectors of Paenibacillus larvae. Apidologie 41: 14-20. http://dx.doi.org/10.1051/apido/2009037

SCHÄFER, M O; RITTER, W; PETTIS, J S; NEUMANN, P (2011) Concurrent parasitism alters thermoregulation in honey bee (Hymenoptera: Apidae) winter clusters. Annals of the Entomological Society of America 104(3): 476-482 http://dx.doi.org/10.1603/AN10142 
SCHEINER, R; ABRAMSON, C I; BRODSCHNEIDER, R; CRAILSHEIM, K FARINA, W; FUCHS, S; GRÜNEWALD, B; HAHSHOLD, S; KARRER, M; KOENIGER, G; KOENIGER, N; MENZEL, R; MUJAGIC, S; RADSPIELER, G; SCHMICKLI, T; SCHNEIDER, C; SIEGEL, A J; SZOPEK, M; THENIUS, R (2013) Standard methods for behavioural studies of Apis mellifera. In V Dietemann; J D Ellis; P Neumann (Eds) The COLOSS BEEBOOK, Volume I: standard methods for Apis mellifera research. Journal of Apicultural Research 52(4): http://dx.doi.org/10.3896/IBRA.1.52.4.04

SCHMOLKE, M D (1974) A study of Aethina tumida: the small hive beetle. University of Rhodesia Certificate in Field Ecology Project Report, 178 pp.

SOLBRIG, A J (2001) Interaction between the South African honey bee, Apis mellifera capensis Esch., and the small hive beetle, Aethina tumida Murray. Diplomarbeit, Freie Universität Berlin, Institut für Zoologie, Berlin, Germany.

SOMERVILLE, D (2003) Study of the small hive beetle in the USA.

Rural Industries Research and Development Corporation, Barton, Australian Capital Territory. 57 pp.

SPIEWOK, S; NEUMANN, P (2006a) Infestation of commercial bumble bee (Bombus impatiens) field colonies by small hive beetles (Aethina tumida). Ecological Entomology 31: 623-628. http://dx.doi.org/10.1111/j.1365-2311.2006.00827.x

SPIEWOK, S; NEUMANN, P (2006b) Cryptic low-level reproduction of small hive beetles in honey bee colonies. Journal of Apicultural Research 45(1): 47-48 http://dx.doi.org/10.3896/IBRA.1.45.1.11

SPIEWOK S; NEUMANN, P (2012) Sex ratio and dispersal of small hive beetles. Journal of Apicultural Research 51(2): 216-217. http://dx.doi.org/10.3896/IBRA.1.51.2.12

SPIEWOK, S; PETTIS, J, DUNCAN, M; SPOONER-HART, R; WESTERVELT, D; NEUMANN, P (2007) Small hive beetle, Aethina tumida, populations I: Infestation levels of honey bee colonies, apiaries and regions. Apidologie 38: 595-605. http://dx.doi.org/10.1051/apido:2007042
SPIEWOK, S; DUNCAN, M, SPOONER-HART, R; PETTIS, J S; NEUMANN P (2008) Small hive beetle, Aethina tumida, populations II: dispersal of small hive beetles. Apidologie 39: 683-693.

http://dx.doi.org/10.1051/apido:2008054

STEDMAN, M (2006) Small hive beetle (SHB): Aethina tumida Murray (Coleoptera: Nitidulidae). Government of South Australia. Primary Industries and Resources for South Australia. Factsheet 03/06: 13 pp.

STRAUSS, U (2009) Small hive beetle (Aethina tumida) behaviour in honey bee (Apis mellifera) colonies. Honours thesis, Social Insect Research Group, Department of Zoology and Entomology, University of Pretoria, South Africa.

WALSH, P S; METZGER, D A; HIGUCHI, R (1991) Chelex 100 as a medium for simple extraction of DNA for PCR-based typing from forensic material. BioTechniques 10(4): 506-513.

WARD, L; BROWN, M; NEUMANN, P; WILKINS, S; PETTIS, J S; BOONHAM, N (2007) A DNA method for screening hive debris for the presence of small hive beetles (Aethina tumida). Apidologie 38: 289-295. http://dx.doi.org/10.1051/apido:2007004

WILLIAMS, G R; ALAUX, C; COSTA, C; CSÁKI, T; DOUBLET, V; EISENHARDT, D; FRIES, I; KUHN, R; MCMAHON, D P; MEDRZYCKI, P; MURRAY, T E; NATSOPOULOU, M E; NEUMANN, P; OLIVER, R; PAXTON, R J; PERNAL, S F; SHUTLER, D; TANNER, G; VAN DER STEEN, J J M; BRODSCHNEIDER, R (2013) Standard methods for maintaining adult Apis mellifera in cages under in vitro laboratory conditions. In V Dietemann; J D Ellis; P Neumann (Eds) The COLOSS BEEBOOK, Volume I: standard methods for Apis mellifera research. Journal of Apicultural Research 52(1): http://dx.doi.org/10.3896/IBRA.1.52.1.04 